\title{
LA EXPULSIÓN DE LOS MORISCOS DEL REINO DE GRANADA EN LOS DOCUMENTOS MUNICIPALES. ESTUDIO ARCHIVÍSTICO
}

\author{
THE MOORISH EXPULSION OF THE \\ KINGDOM OF GRANADA THROUGH THE \\ MUNICIPAL DOCUMENTS. ARCHIVAL STUDY
}

\author{
MARIANO GARCÍA RUIPÉREZ \\ Archivo Municipal de Toledo
}

\begin{abstract}
Resumen: En este artículo se analiza el origen y características de los documentos conservados en los archivos municipales relacionados con el repartimiento por tierras de Castilla de los moriscos expulsados del Reino de Granada desde el levantamiento de las Alpujarras, a finales de 1568, hasta su expulsión a partir de 1609. Para ello se ha analizado la normativa aprobada en la época, especialmente la Real Pragmática de 26 de octubre de 1572 y otras reales provisiones complementarias, y se ha comprobado su cumplimiento mediante el estudio de los documentos conservados en el Archivo Municipal de Toledo relacionados con esta minoría.
\end{abstract}

Palabras clave: España, Historia, Edad Moderna, Felipe II, sociedad, minorías, moriscos, Ayuntamientos, documentos, tipología documental.

\begin{abstract}
This article describes the origin and characteristics of the documents preserved in the municipal archives relating to the distribution of the Moorish expelled from the kingdom of Granada along the lands of Castile, since the rising of the Alpujarras, in late 1568, until their expulsion from 1609. Have been analysed the rules adopted at the time, specially the Real Pragmática of 26 October 1572 and other complementary royal texts, and verified their compliance through the study of the documents preserved in the Archivo Municipal of Toledo associated with this minority.
\end{abstract}

Keywords: Spain, History, Modern Times, Felipe II, society, minorities, Moorish, municipal governments, documents, documentary typology.

Felipe III, por una pragmática firmada en Madrid el 9 de diciembre de 1609 mandó "que todos los moriscos habitantes en estos Reynos, assí hombres como mugeres, y niños, de qualquier condición que sean, assí los nacidos en ellos, como los estrangeros, fuera de los esclavos, dentro de treynta días salgan destos Reynos, y límites de España, contados desde el día de la publicación de esta ley; prohibiendo, como prohibimos, que no puedan bolver a ellos, so pena de la vida, y per- 
dimiento de bienes, en que desde luego incurran, sin otro processo, ni sentencia" ${ }^{\text {. }}$ Con esta disposición, que tardó algunos años en aplicarse de manera efectiva, se ponía fin a la presencia de personas libres de religión musulmana en España, iniciada con la invasión del año 711.

Desde las capitulaciones firmadas en Santa Fe, el 25 de noviembre de 1491, la cuestión morisca pasó a un primer plano en la política interior castellana. Por ellas a los musulmanes granadinos se les permitió el uso de su derecho y de su lengua, y se les garantizó la libertad religiosa y la conservación de sus propiedades, incluidas mezquitas y escuelas. Pero muy pronto, la intransigencia del cardenal Cisneros propició medidas menos tolerantes que culminarían con el decreto de 12 de febrero de 1502 por el que los Reyes Católicos conminaban a los musulmanes, no esclavos, de los Reinos de Castilla y León a que eligieran entre la conversión al cristianismo o la expulsión de España por los puertos de Vizcaya ${ }^{2}$. La mayoría optó por lo primero, al menos sobre el papel, siendo conocidos en la época como "cristianos nuevos de moro" o "moriscos".

Por Real Cédula de 12 de mayo de 1511, quedó garantizada la validez jurídica de las escrituras de "casamientos, posesiones, testamentos y otros cualesquier documentos" hechas por los moros del Reino de Granada antes de su conversión forzosa de $1502^{3}$. En 1515, por otra disposición, firmada en Arévalo, el rey Fernando prohibió a los moriscos de Castilla, León, Aragón, Valencia y Cataluña que pudieran entrar en el Reino de Granada, bajo pena de muerte y de pérdida de todos sus bienes ${ }^{4}$.

Carlos V, en 7 de diciembre de 1526, aprobó una serie de medidas, conocidas como "los capítulos de la Congregación de Granada" por las que se prohibía a los moriscos el uso de insignias propias, de armas, de sus nombres o sobrenombres musulmanes, etc., pero les concedió un plazo de cuarenta años para hacerlas efectivas.

En esos capítulos se incluían aspectos que podían tener cierta incidencia documental a nivel municipal. Así en el tercero se especificaba que ningún cirujano, médico u otra persona podía cortar el prepucio del miembro de un morisco sin expresa licencia del prelado o del corregidor. Por el sexto se prohibía usar y portar

\footnotetext{
${ }^{1}$ Recopilación de las leyes destos reynos hecha por... don Felipe Quarto. Segunda parte de las Leyes del Reyno, Madrid, 1640, Libro Octavo, Título II, Ley XXII, h. 299v.

${ }^{2}$ Ídem, Libro Octavo, Título II, Ley IIII, h. 290v-292.

${ }^{3}$ Ídem, Libro Octavo, Título II, Ley XI, h. 293.

${ }^{4}$ Los códigos españoles concordados y anotados. Tomo undécimo. Leyes de la Nueva Recopilación que no han sido comprendidas en la Novísima, Madrid, 1850, p. 232.

${ }^{5}$ Recopilación de las leyes destos reynos..., Libro Octavo, Título II, Ley XIII, h. 293-294v.
} 


\section{MARIANO GARCÍA RUIPÉREZ \\ LA EXPULSIÓN DE LOS MORISCOS DEL REINO DE GRANADA EN LOS DOCUMENTOS MUNICIPALES...}

armas a los moros convertidos, por lo que todos los que tenían licencias para ello debían presentarlas ante los corregidores de su jurisdicción, que estudiarían quiénes las podían llevar e informarían al Rey sobre esta cuestión. Es decir, si estos capítulos se cumplieron, es posible que en las localidades del Reino de Granada, que fueran cabeza de corregimiento, se tramitaran expedientes de concesión de licencias para el uso de armas o de autorización de corte del prepucio por médicos o cirujanos a miembros de ese colectivo. Lo primero es más factible porque el portar armas era un signo de preeminencia social y los que hubieran obtenido esa licencia de las autoridades cristianas intentarían no perderla. Lo segundo es más descabellado. Los moriscos varones, siguiendo sus costumbres, serían circuncidados durante su niñez por sus propios médicos o cirujanos en la intimidad de sus casas. Solicitar licencia al prelado o al corregidor solo produciría inconvenientes.

Entre los capítulos de la "Congregación de Granada" se incluía otro, el quinto, por el que se ordenaba que los moriscos debían formalizar sus cartas de dote y otros instrumentos públicos ante escribanos y notarios que fueran cristianos viejos, prohibiendo que lo hicieran ante escribano "que sea nuevamente convertido de moro". Pero no en todas las localidades del antiguo reino de Granada se avecindaron escribanos cristianos viejos.

El largo plazo dado por Carlos V para la aplicación de esos capítulos, cuarenta años, permitió que la mayoría de los musulmanes conversos siguieran viviendo según sus costumbres y su cultura, practicando sus ritos con discreción y sirviendo a su fe. Los tribunales inquisitoriales no persiguieron sus prácticas tradicionales y cuando actuaron lo hicieron con menos rigor que contra los judeoconversos.

En 1566, una vez pasado el plazo indicado, Felipe II creyó conveniente que los moriscos abandonaran tanto sus ritos y costumbres como su lengua y su cultura. El papa Pío V le animó a tomar esa decisión, pues conocía que su conversión no era real. Por una Pragmática de 17 de noviembre de $1566^{6}$, publicada el 1 de enero de 1567, el rey dio tres años de plazo a los moriscos para que aprendieran la lengua castellana, pues pasado ese tiempo ninguno de ellos podía hablar, escribir o leer en lengua arábiga. En ella se especificaba, también, que todos los contratos, testamentos y otros documentos escritos en esa lengua no tendrían ningún valor. A las moriscas se les obligaba a vestir como lo hacían las cristianas, con mantos y sayas, llevando siempre el rostro descubierto, por lo que se les prohibía el uso de sus trajes tradicionales ("almalafas y marlotas"). Tampoco podían llamarse con

${ }^{6}$ Ídem, Libro Octavo, Título II, Leyes XV-XVIII, h. 294v-295v. 
nombre o sobrenombre de moros. Y en sus fiestas (bodas, velaciones...) debían seguir las costumbres de los cristianos viejos, manteniendo siempre en esos casos las puertas de sus casas abiertas; lo mismo tenían que hacer los viernes por la tarde, y los domingos y festivos. Felipe II les prohibía, además, realizar “zambras” y "leilas", es decir sus fiestas tradicionales con sus cantes y bailes.






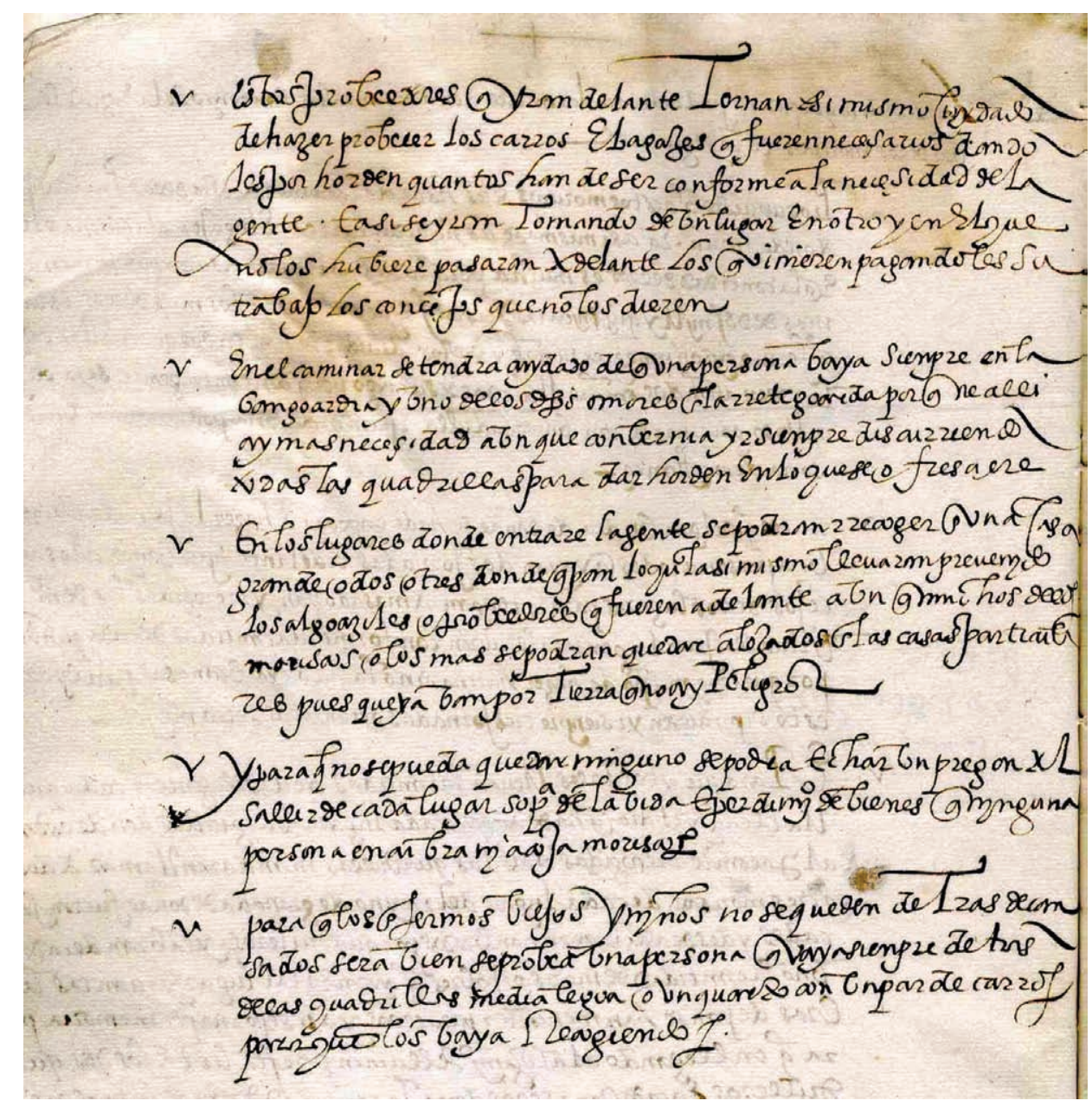

Reglas para el traslado de los moriscos de Granada (XII-1570).

El descontento de los moriscos con la aplicación de esta pragmática desembocó, como sabemos, en la sublevación de las Alpujarras granadinas en diciembre de 1568, aunque la inestabilidad social era patente desde años atrás ${ }^{7}$. De ahí se extendió a otras zonas del antiguo Reino de Granada, especialmente del medio rural. Tras una dura campaña militar, las tropas mandadas por Don Juan de Austria consiguieron doblegar a los sublevados en el verano de 1570. Poco después se tomó la medida de expulsar a todos los moriscos granadinos de ese Reino, inclu-

${ }^{7}$ El 23 de noviembre de 1567, Felipe II hizo pública una norma por la que castigaba duramente a los moriscos del Reino de Granada que ayudaran a los "monfíes y salteadores que andan en el campo". Su contenido puede leerse en Los códigos españoles..., Tomo XI, pp. 236-237. Por otra de 10 de diciembre de 1567, recogida también en esa obra, en las pp. 238-239, extendía las penas a los moriscos que ayudaban a los turcos y moros corsarios que asaltaban las costas españolas. 
yendo a los realmente convertidos a la fe cristiana, trasladándoles a otras partes de Andalucía, de la Castilla mesetaria y de Extremadura ${ }^{8}$.

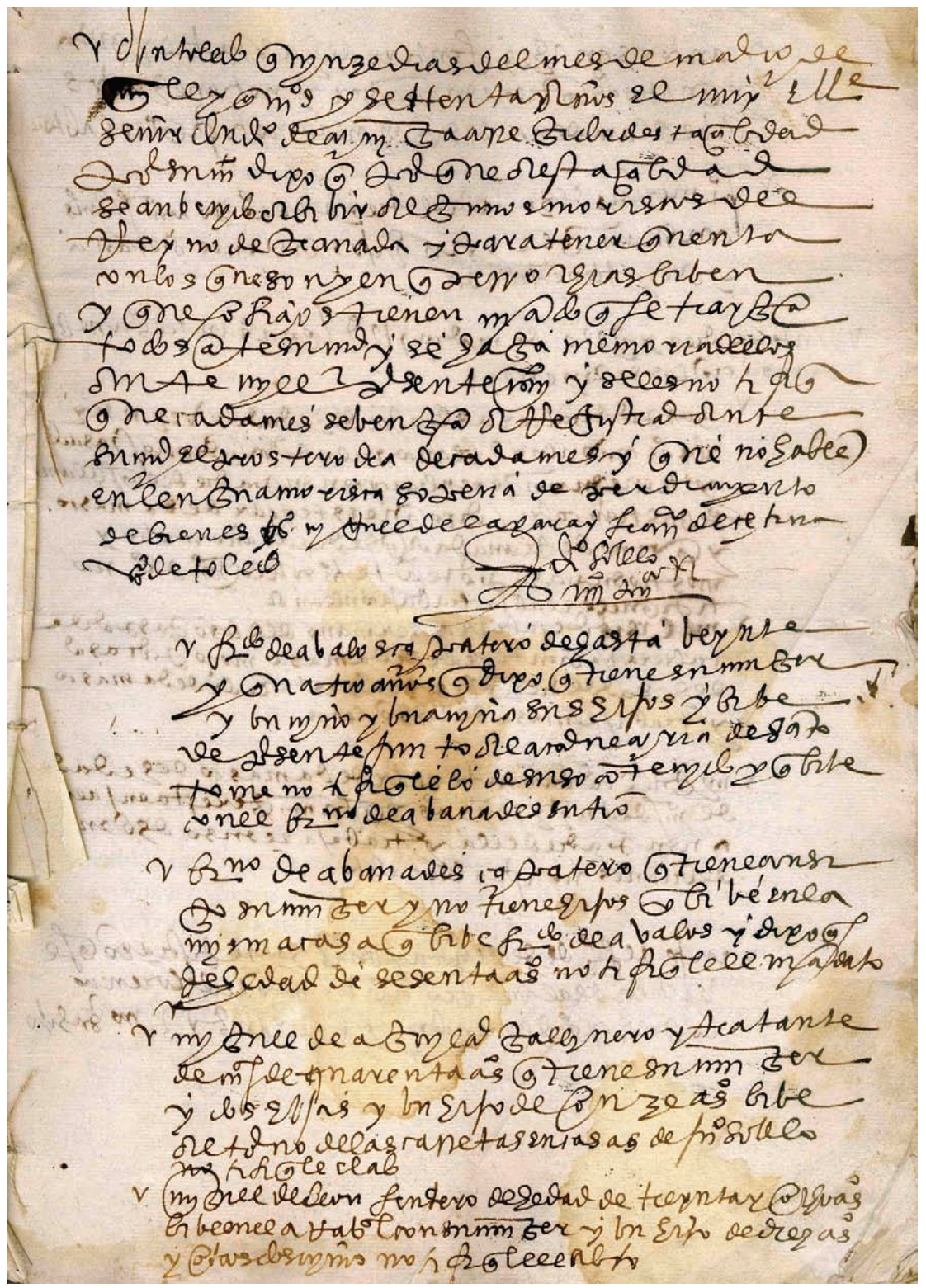

Registro de moriscos libres de la ciudad de Toledo (15-III-1570).

${ }^{8}$ Para este tema, y en general para el estudio de la minoría morisca, son referentes clásicos las aportaciones del hispanista francés B. Vincent. En concreto recomendamos las siguientes: B. VINCENT, "L'expulsion des morisques du Royaume de Grenade et leur répartition en Castille (1570-1571)", Melanges de la Casa de Velázquez, 6 (1970), pp. 211-246; Ídem, "La cuestión morisca. La sublevación de 1568-1570”, en La monarquía hispánica Felipe II, un monarca y su época: Real Monasterio de San Lorenzo del Escorial, 1 de junio, 10 de octubre, 1998, Madrid, 1998, pp. 285-290; e Ídem, "L'expulsion des morisques", en Calderón de la Barca y la España del Barroco, Vol. 1, Madrid, 2003, pp. 505-514. 
El 24 de febrero de 1571, Felipe II firmó en Aranjuez una Real Provisión por la que daba cuenta de las medidas adoptadas a las autoridades de sus reinos y señoríos para conseguir una rápida repoblación con "cristianos viejos" de las localidades del reino de Granada, de donde habían tenido que salir a la fuerza sus antiguos habitantes moriscos. Junto con medidas generales hacendísticas, de seguridad y de orden público, ordenó la distribución entre los nuevos repobladores de los bienes de los moriscos (casas, heredades, viñas y huertas...) bajo ciertas condiciones, pues su propiedad pertenecía a la Corona. Ese mismo día se data en Madrid la "Instrucción para los concejos e justicias sobre lo tocante a los pobladores que han de yr al reyno de Granada" en la que se recogen normas que debían cumplir las autoridades locales para promover que algunos de sus vecinos marcharan a repoblar ese Reino. De entre los interesados debían preferir a los casados, que irían acompañados de sus familias, dedicados a la labranza o a la cría de la seda. En cada concejo, su escribano llevaría un registro y memorial en el que anotaría "los nombres de las personas que quieren yr, declarando de dónde son y de qué oficio y calidad, y si son casados, o no y todo lo demás que paresciere se declare". Esos registros o memoriales se debían enviar a la población cabeza de partido para su conocimiento, pues no en vano se pretendía que todos los que quisieran emigrar desde cada partido lo hicieran juntos ${ }^{9}$.

El contenido de esa Instrucción fue recordado de nuevo por otra de 15 de octubre de 1571. También ese día se aprobó en Madrid una nueva Real Provisión que copiaba la anterior de 24 de febrero pero le añadía nuevos capítulos ampliando las gracias y exenciones. Por uno de ellos se otorgaba la propiedad de las tierras recibidas a los nuevos pobladores si pasados cuatro años las tenían bien labradas, con la única condición de pagar perpetuamente la décima parte de todo lo recolectado en concepto de impuesto. Por otro se establecía un censo, por valor de un real cada año, sobre las casas recibidas de los antiguos moriscos ${ }^{10}$.

Para controlar la repoblación con cristianos viejos de las localidades granadinas se había constituido un Consejo de Población de Granada a finales de 1570 que desarrolló sus funciones hasta su disolución en 1592.

Entre los documentos generados por los nuevos ayuntamientos surgidos tras la llegada de los repobladores en esas antiguas poblaciones del Reino de Granada

\footnotetext{
${ }^{9}$ Ejemplares impresos de la Real Provisión y de la Instrucción de 24 de febrero de 1571 se conservan en el Archivo Municipal de Toledo (= AMT), caja 1686.

${ }^{10}$ Este documento fue publicado con el título de Provisión Real de su Magestad, de las gracias, mercedes, franquezas que de nueuo concede a los que fueren a poblar a las Alpuxarras, sierras y marinas del Reyno de Granada, en Madrid: en casa de Alonso Gómez, impressor de su Magestad, 1571, [14] p. Un ejemplar de este impreso se conserva en el AMT, caja 1686.
} 


\section{MARIANO GARCÍA RUIPÉREZ \\ LA EXPULSIÓN DE LOS MORISCOS DEL REINO DE GRANADA EN LOS DOCUMENTOS MUNICIPALES...}

destacará por su importancia el "Libro de apeo" de cada localidad, en donde constaba el "apeo y deslindamiento, la formación de las suertes, los vecinos que vinieron a poblar y las suertes que a cada uno le hubieren pertenecido" 11 . Esos libros de apeo, realizados la mayoría entre 1571 y 1574, han sido objeto de importantes estudios e interesantes transcripciones ${ }^{12}$.

${ }^{11}$ Y. QUESADA MORILLAS, "Los moriscos del Reino de Granada: su expulsión y el Consejo de Población", Revista electrónica de la Facultad de Derecho de la Universidad de Granada (30 de octubre de 2008), p. 14.

12 Para el estudio de los libros de apeo y repartimiento de poblaciones del reino de Granada es indispensable la consulta de la obra de M. BARRIOS AGUILERA y M. M. BIRRIEL SALCEDO, La Repoblación del Reino de Granada después de la expulsión de los moriscos, Granada, 1986. Se reproducen y estudian algunos de estos libros en las siguientes publicaciones: J. ABELLÁN PÉREZ, M. ESPINAR MORENO y Ma M. GARCÍA GUZMÁN, Apeos y repartimiento de Hijar (Las Gabias), Granada, 2007; M. BARRIOS AGUILERA, Moriscos en la tierra de Loja: el apeo de 1571-1574: estudio y edición, Loja, 1986; Ídem: "Paisajes agrarios moriscos en Granada (a través de los Libros de Apeo)", Revista del Centro de Estudios Históricos de Granada y su Reino, 3 (1989), pp. 217-238; Ídem: "Los moriscos de la Vega de Granada: la agricultura (a través de los Libros de Apeo)", en IV Simposio Internacional de Mudejarismo: Economía: actas: Teruel, 17-19 de septiembre de 1987, Teruel, 1993, pp. 597-614; J. J. BRAVO CARO, El apeo y repartimiento de Algarrobo, Algarrobo, 1998; J. BUSTAMANTE y J. ABELLÁN, "Toponimia hispanoárabe y mozárabe del libro de apeo en Cantabria (Almería)", Anales de la Universidad de Cádiz, 3-4 (1986-1987), pp. 171-188; Ma C. CALERO PALACIOS, El apeo y repartimiento de Cenes de la Vega: edición y estudio de algunos aspectos, Granada, 1987; M. ESPINAR MORENO [et al.], El Valle: libros de apeo y repartimiento de Melegís y Restábal, [El Valle, Granada], 2006; M. ESPINAR MORENO y M. GONZÁLEZ MARTÍN, Libro de apeo y repartimiento de Mondújar (Valle de Lecrín), Granada, 2008; M. FERRER, Libro de apeo y repartimiento de suertes de Guexar de la Sierra, [Güéjar Sierra], 1999; Ídem: Libro del Apeo y Repartimiento de Suertes del lugar de Nigüelas: año 1572, Nigüelas (Granada), 2000; Ídem: Libro del Apeo y Repartimiento de Suertes del lugar de Lanjarón, año 1572, Lanjarón (Granada), 2001; Ídem, Libro de Apeo y Repartimiento de Suertes de Las Albuñuelas, Albuñuelas (Granada), 2003; Ídem, Libro de Apeo y Repartimiento de suertes del lugar de Trevélez, partido de Al-Puxarras: año 1572, Granada, 2007; M $^{\mathrm{a}} \mathrm{D}$. GUERRERO LAFUENTE y Ma A. ÁLVAREZ CASTILLO, “Apeo de Canjayar: Introducción, edición e índices", Cuadernos de estudios medievales y ciencias y técnicas historiográficas, 16 (1991), pp. 191-222; M. MARCOS ALDÓN [y otros], "Edición del apeo y repartimiento de Beas de Guadix (Granada)", Cuadernos de estudios medievales y ciencias y técnicas historiográficas, 20 (1995), pp. 215-290; J. M. MARTÍNEZ LÓPEZ, "El apeo de Lubrin: siglo XVI”, en Almería entre culturas: (siglos XIII-XVI), Vol. 2, Almería, 1990, pp. 821-838; Ma D. MARTÍNEZ SAN PEDRO, M. GARCÍA PARDO, Bayarque: el Libro de Apeo y Población de 1572, Almería, 2001; C. MUÑOZ MORALES, "El proceso repoblador de 1572 en Benadalid (Málaga) según su libro de apeo y repartimiento", en Actas VI Congreso Histórico sobre Nuevas Poblaciones: La Carlota, Fuente Palmera, San Sebastián de los Ballesteros, 11 al 14 de mayo de 1994, Córdoba, 1994, pp. 475482; F. A. PAREJA PAREJA y C. PERDIGUERO AYALA, "La villa de Arenas (Málaga) en el libro de apeo y repartimiento, una aproximación etnoarqueológica", en Felipe II y su tiempo. $V$ Reunión Científica Asociación Española de Historia Moderna, Vol. 1, Cádiz, 1999, pp. 519-528; E. RODRÍGUEZ BECERRA, Igualeja después de la expulsión de los moriscos (1572-1742), Ronda, 2005; J. A. SAMPER PADILLA y C. E. HERNÁNDEZ CABRERA, "Los arabismos del Libro de apeo y repartimiento del lugar de Cartaunas (Granada)", Philologica canariensia: Revista de filología de la Universidad de Las Palmas de Gran Canaria, 1 (1995), pp. 381-408; E. SORIA 


\section{MARIANO GARCÍA RUIPÉREZ \\ LA EXPULSIÓN DE LOS MORISCOS DEL REINO DE GRANADA EN LOS DOCUMENTOS MUNICIPALES...}

Pero no es nuestra intención detenernos ahora en los documentos generados en los nuevos ayuntamientos del Reino de Granada creados tras la salida de los moriscos, sino en la generada en las poblaciones a donde fueron enviados los expulsos. Y para ello es imprescindible conocer la Real Pragmática de 26 de octubre de 1572 por la que Felipe II regulará el control de los moriscos repartidos por tierras castellanas, tras la victoria de las tropas mandadas por Don Juan de Austria ${ }^{13}$. Y a su análisis vamos a dedicar los siguientes párrafos.

Por esta importante disposición el monarca español ordenará que en todas las poblaciones receptoras, fueran ciudades o aldeas, se hiciera "lista y registro de todos los moriscos, así libres como esclavos del dicho Reino de Granada, y de sus mujeres e hijos, poniéndose en el registro los nombres de todos, y de donde fueren traídos y son naturales, según que ellos lo declararen; poniendo así mismo la edad y señas de estatura y rostro, y el oficio, y trato que tuviere, y la casa y parroquia donde viviere" ${ }^{14}$. Ese registro debía ser elaborado por la justicia, en clara referencia al alcalde o, en su caso, al corregidor, y por uno o dos regidores en presencia del escribano del concejo o ayuntamiento. Los datos se asentarían en un libro, iniciado con el traslado del texto de esta pragmática, que debía conservarse en el arca del concejo, es decir en el primitivo archivo del común o archivo municipal.

En las poblaciones que eran cabezas de corregimiento se debía recibir copia de los registros de moriscos realizados en los lugares de su jurisdicción. La información aportada desde esas localidades debía asentarse también en el registro mencionado. Era importante, además, anotar en esas listas todas las variaciones que pudieran producirse, bien por muerte, por nacimiento o por otras causas, por lo que su continua actualización dependía de las relaciones que pudieran suministrar los curas párrocos $\mathrm{u}$ otras personas que pudieran tener ese cometido en las distintas parroquias.

Además, quería el Rey que de cada registro se hicieran dos copias. Una se entregaría al prelado (obispo o arzobispo) que a su vez daría la información precisa a cada uno de sus párrocos, y la otra estaría en poder del regidor nombrado cada año, o por más tiempo, como superintendente, patrón y defensor de los moriscos. Este cargo debía existir en "cada uno de los lugares principales". Este regidor

MESA, V. SÁNCHEZ RAMOS y C. GAYA LÓPEZ, "El paisaje de Canjayar a través de su apeo", en Almería entre culturas: (siglos XIII-XVI), Vol. 2, Almería, 1990, pp. 789-800.

${ }^{13}$ Por otra Pragmática, fechada el 6 de octubre de 1572, el Rey trató sobre "los moriscos esclavos que fueron tomados en el reyno de Granada y la orden que con ellos se ha de tener". Esta pragmática fue impresa en Madrid, en casa de Alonso Gómez, en 1573.

${ }^{14}$ Recopilación de las leyes destos reynos hecha por... don Felipe Quarto, Libro Octavo, Título II, Ley XIX, h. 295v. 
era designado por el ayuntamiento, que también se encargaba de nombrar a un jurado o a otra persona en cada una de las parroquias de la localidad con el mismo cometido. Estos últimos disponían de una lista o registro parcial de los moriscos que residían en su parroquia, y ayudarían al regidor superintendente y a la justicia cuando fueran requeridos.

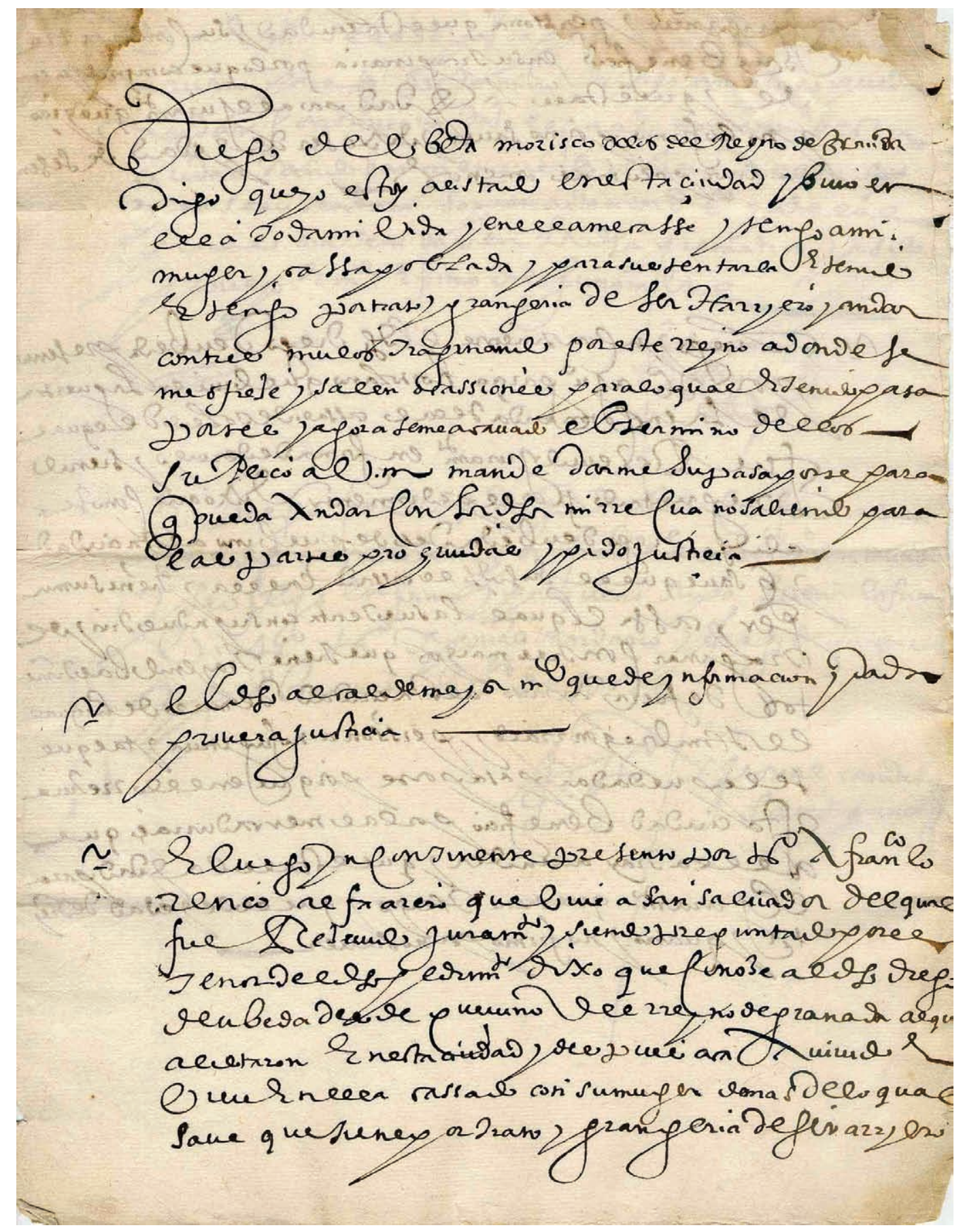


?

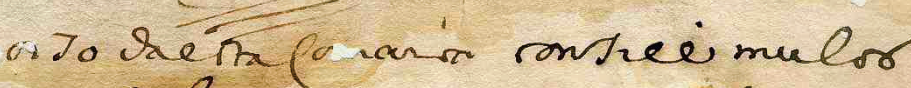

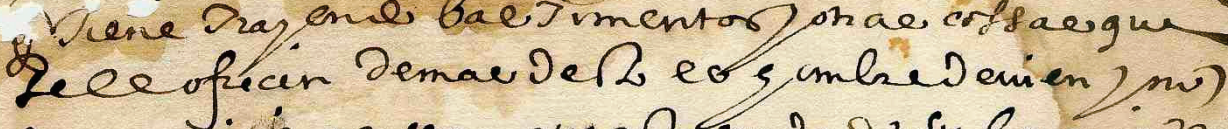

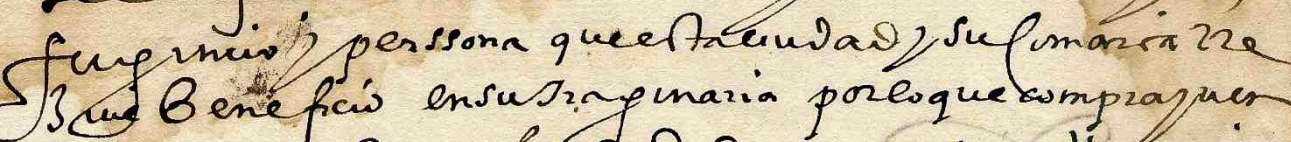

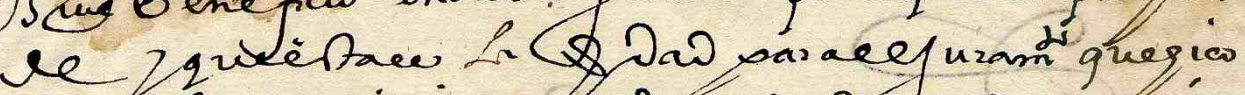

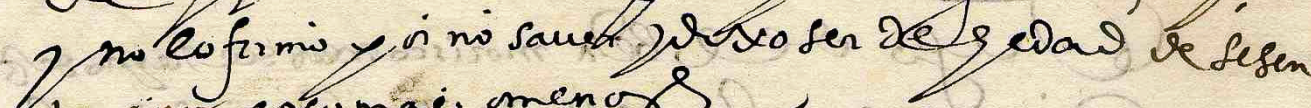
to ante potumai menor

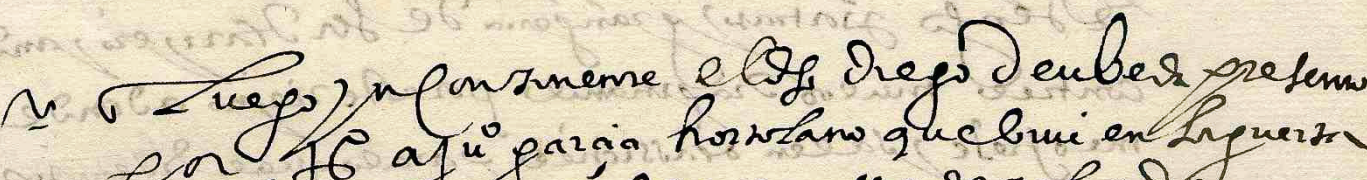

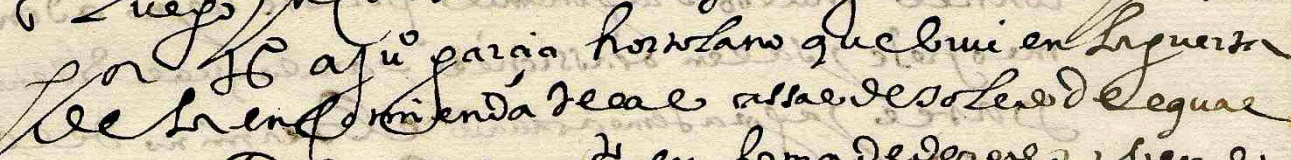

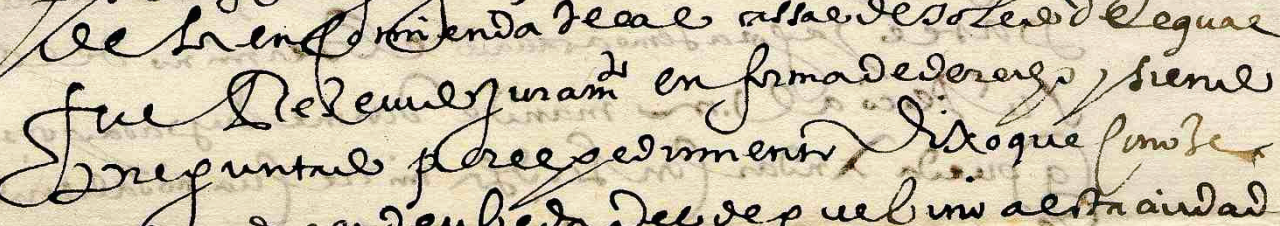

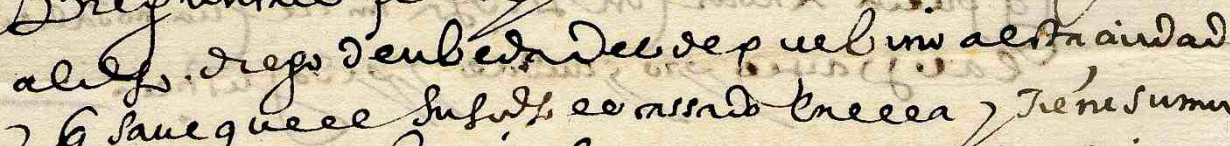

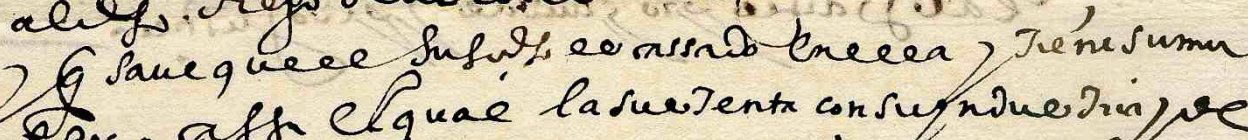
ger, rafs elquae la suctenta consupnowiripe

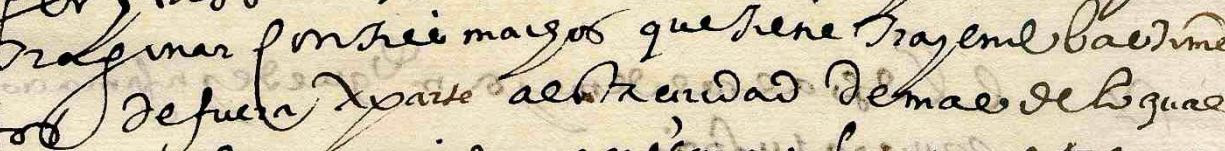
tot defura de mae ve fune

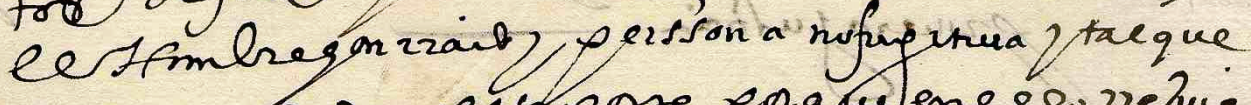

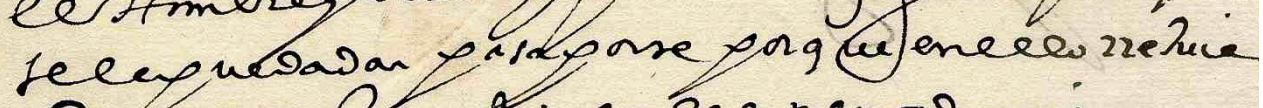

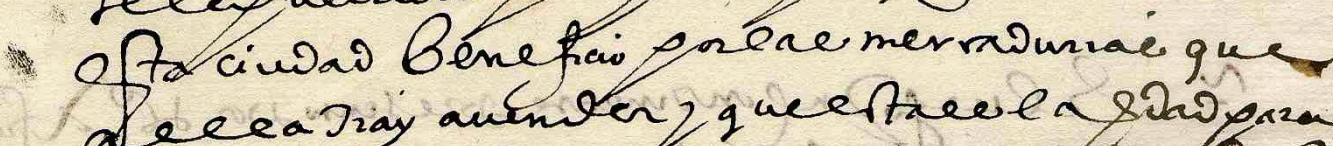

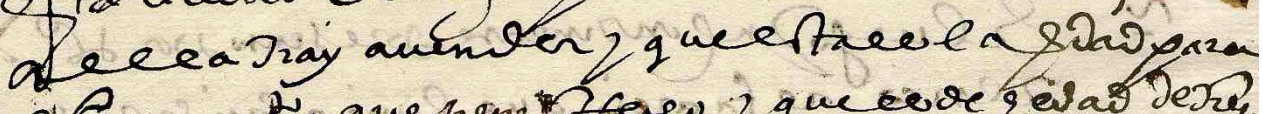

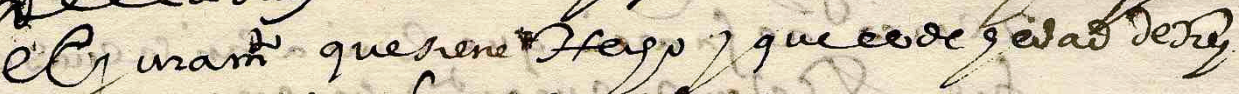

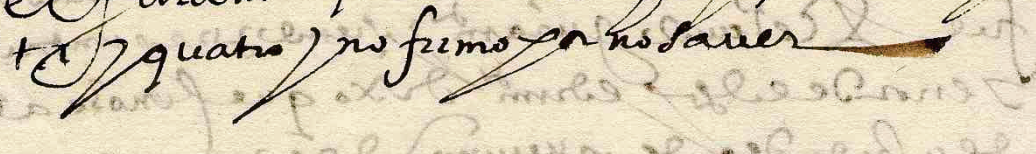

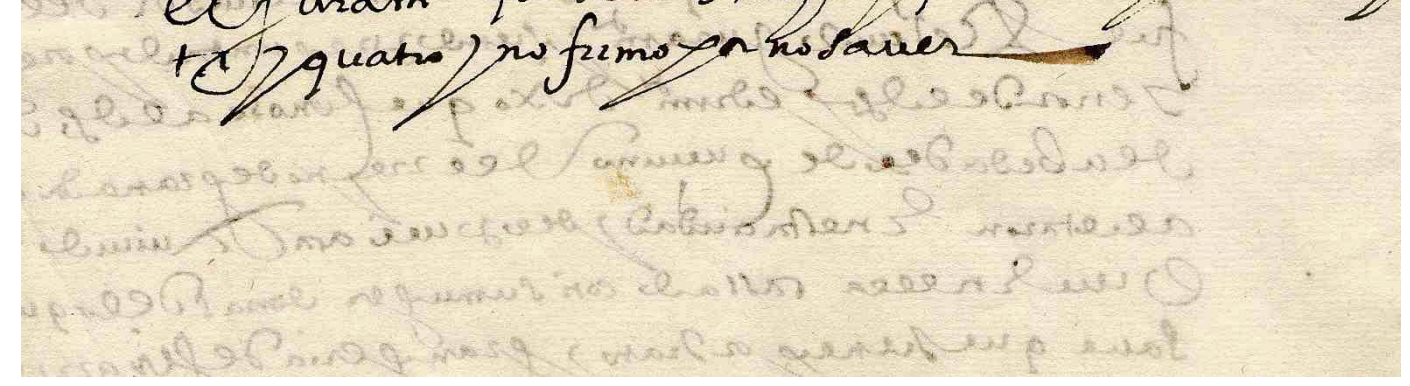




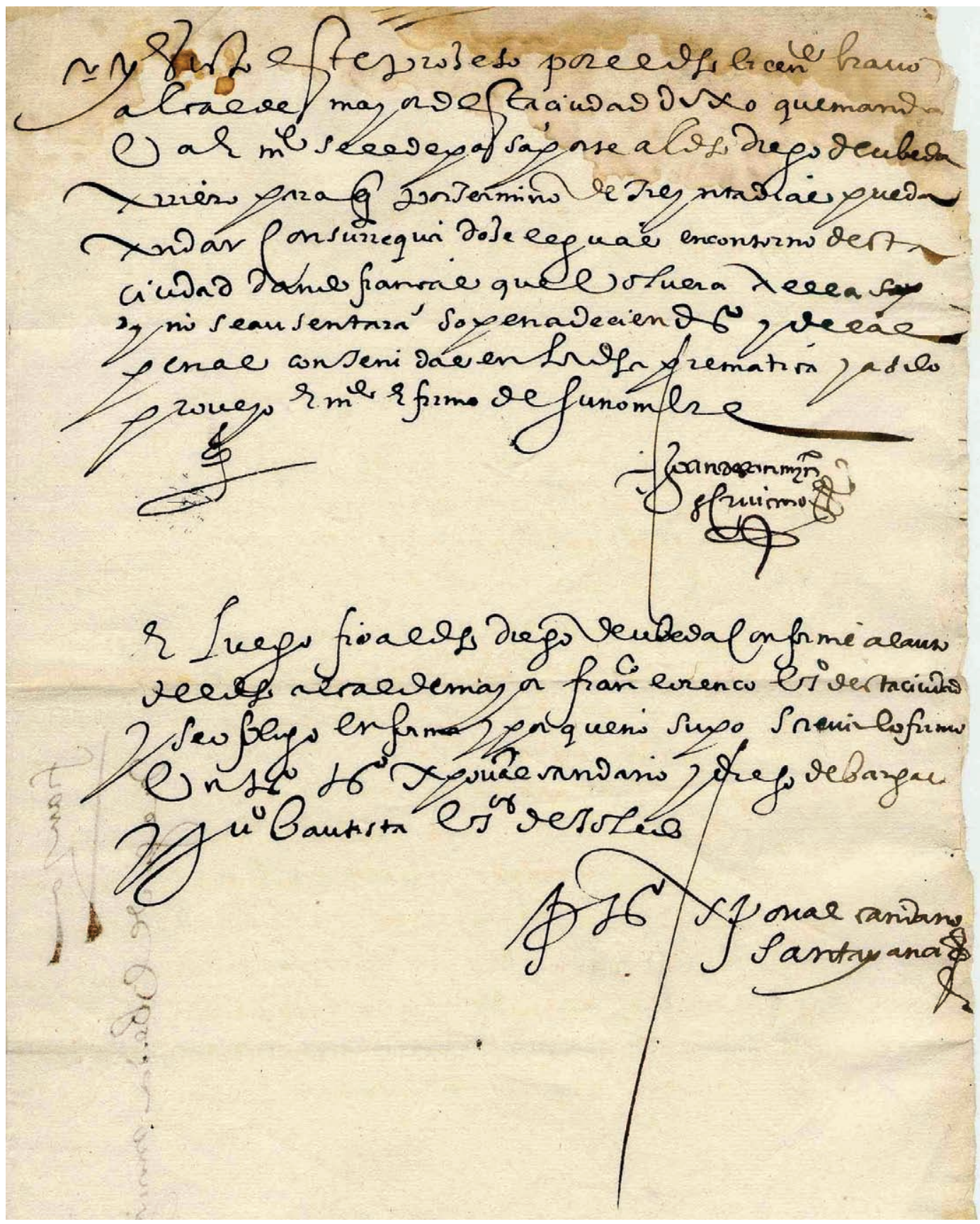

Expediente de solicitud de licencia de ausencia (1588).

En la pragmática comentada se establecía, también, que ningún morisco de los repartidos podía mudarse, salir o ausentarse de los lugares a donde había sido destinado sin "expresa y particular licencia de la justicia del lugar", dada por escrito y firmada tanto por ella (alcalde o corregidor) como por el escribano del concejo o ayuntamiento. En esa licencia, expedida sin ningún coste para el solici- 
tante, figuraba el nombre y señas del morisco, el lugar a donde iba y el periodo de tiempo por el que se autorizaba su ausencia. Pero había limitaciones. En ningún caso se podían emitir para viajar al Reino de Granada. Los peticionarios debían demostrar ser personas "seguras y sin sospecha", tomando las seguridades que se considerasen precisas, por lo que generalmente se requería que fueran avalados por fiadores.

Estas licencias se concedían fundamentalmente a personas que necesitaban desplazarse desde su lugar de vecindad a poblaciones cercanas por cuestiones laborales (arrieros, artesanos, jornaleros...). La licencia les permitía estar ausentes durante unos días o semanas. Más dificultades tenían aquellos que querían irse a vivir a otras localidades, pues la concesión de estas licencias no dependía de las justicias sino del Rey. Incluso el traslado de domicilio dentro de una misma localidad debía ser comunicado previamente al cura de la parroquia de origen y al de la de destino, o persona encargada, para que hicieran las oportunas anotaciones en su lista.

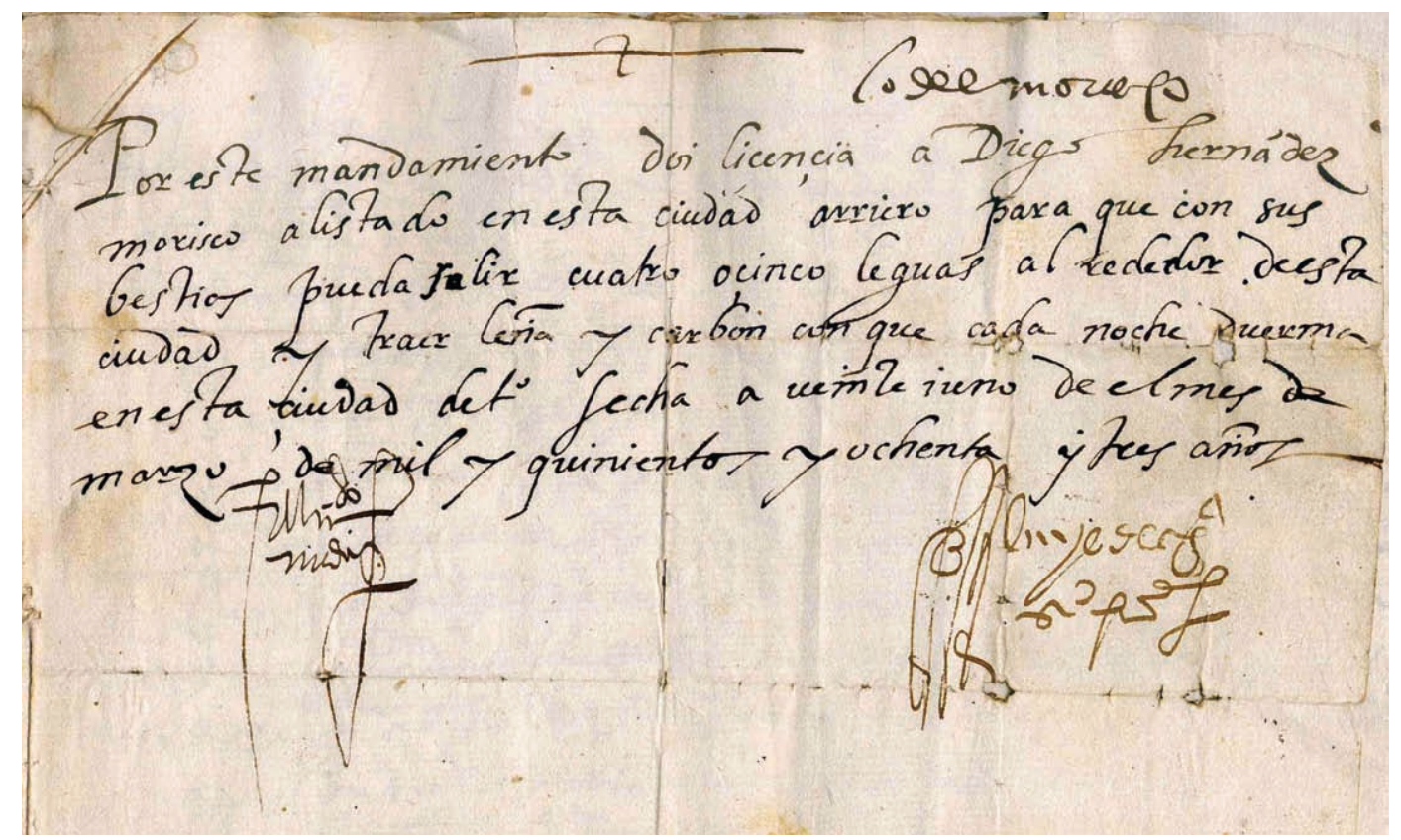

Licencia a un morisco para que pueda salir cada día de Toledo (21-III-1583).

La contravención de esta disposición, y en especial la de que los moriscos volvieran sin autorización al Reino de Granada o a diez leguas en su contorno, acarreaba la pena de muerte para todos los varones adultos. Ahora bien, si se tenía una edad comprendida entre diez y medio y diecisiete años la pena incurrida era la de esclavitud. Las mujeres, siempre que tuvieran más de nueve años y medio, 
MARIANO GARCÍA RUIPÉREZ
LA EXPULSIÓN DE LOS MORISCOS DEL REINO DE GRANADA EN LOS DOCUMENTOS MUNICIPALES...

también serían esclavizadas. Los niños y niñas con edades inferiores serían entregados a familias cristianas para ser instruidos y educados, y con ellas permanecerían hasta cumplir los veinte años.

Esas duras penas se atemperaban, es un decir, si los moriscos eran detenidos cerca, en torno a diez leguas, de los reinos de Aragón, Valencia o Navarra. Entonces, los varones adultos eran destinados al servicio perpetuo en galeras, permaneciendo igual el resto de las penas. Y si eran detenidos, sin licencia, en otras partes de los reinos, se les condenaba a cien azotes y a cuatro años de galeras.

La pragmática de 1572 incide en el control y localización de los moriscos expulsos ordenando la comunicación a las justicias de cualquier ausencia por parte de las personas que convivieran con ellos en sus mismas casas. Ordena la mayor diligencia en su persecución, de tal forma que se entienda la busca y captura de los huidos como casos de Hermandad. Y castiga a todos los que pudieran prestarles ayuda, fueran también moriscos o fueran cristianos viejos, y premia a los que los detuvieran, sin tener este especial cometido.

También se detiene en la prohibición del uso de cualquier arma por parte de los moriscos, si no tenían licencia expresa para ello del Rey. De tal forma que solo se les autoriza a tener para su servicio "un cuchillo sin punta", bajo severas penas.

La integración de esta minoría en las localidades castellanas de acogida pretendía basarse en que no residieran en barrios propios sino junto a o en las casas de los cristianos viejos. Se procuraría que los niños de corta edad fueran entregados a eclesiásticos, o a personas de las principales de cada pueblo, para su educación por un tiempo determinado. Los padres debían trabajar en sus oficios en casas de cristianos viejos, recibiendo por ello su salario. Las justicias debían velar porque los moriscos no estuvieran ociosos y se ganaran su sustento con su trabajo.

Unos meses antes, por una Real Provisión, dada en Madrid el 20 de julio de 1572, Felipe II había ordenado que los hijos de los moriscos sublevados del Reino de Granada fueran considerados esclavos siempre que tuvieran más de diez años y medio (los varones) o más de nueve y medio (las hembras). Los de edades inferiores no tendrían esa consideración pero no se podían quedar con sus padres ya que tenían que ser entregados a familias cristianas que los educarían e instruirían hasta la edad de veinte años en que quedarían libres, como los demás moriscos que no fueron apresados durante la sublevación. Las familias de acogida se tenían que comprometer a que aprendieran en las escuelas a leer y escribir, y a recibir formación en doctrina cristiana.

La pragmática de 1572, que estamos analizando, establece, también, que los moriscos no podían tener libros ni documentos escritos en árabe, y los que tuvie- 


\section{MARIANO GARCÍA RUIPÉREZ \\ LA EXPULSIÓN DE LOS MORISCOS DEL REINO DE GRANADA EN LOS DOCUMENTOS MUNICIPALES...}

ran debían entregarlos a las justicias del lugar en el que residieran. Ahora bien, podían recibir copia autenticada de algunas de esas escrituras, en especial de las relacionadas con sus propiedades, pero traducidas al castellano, quedando los originales en poder del escribano del concejo o ayuntamiento. A partir de entonces cualquier documento escrito en lengua arábiga, tanto los contratos como otras escrituras públicas y privadas, carecerían de valor legal.

Es difícil valorar el impacto real de esta disposición concreta de la pragmática de 1572, pero su aplicación explicaría la presencia de documentos privados escritos en árabe en algunos archivos municipales españoles. Aunque no parece que sea este el caso de la ciudad de Toledo ${ }^{15}$.

También, y como ya se había hecho en 1566, se prohibió a los moriscos que pudieran hablar y escribir en lengua arábiga, bajo duras penas, aunque se tratara de cartas personales, memorias, etc., manteniéndose las mismas medidas en lo relacionado con los bailes, zambras, cantos, música, etc.

Para verificar el cumplimiento del contenido de esta pragmática de 1572, Felipe II terminaba en ella ordenando a las justicias que hicieran visitas generales a los moriscos que residían en sus localidades una vez al mes, hasta que se ordenara otra cosa. El regidor superintendente debía hacerla cada quince días y los jurados, o personas diputadas de cada parroquia, junto con el cura párroco, una vez a la semana. Esas visitas, cuyo contenido pudo formalizarse por escrito, aunque esta norma no diga nada sobre ello, tenían que servir para conocer cómo vivían los moriscos y para controlar su población, poniendo especial cuidado en la atención de pobres y enfermos.

La Pragmática de 26 de octubre de 1572 fue la norma más importante aprobada sobre la población morisca en toda la segunda mitad del siglo XVI, y la que más influyó en la producción documental relacionada con esta minoría en las poblaciones castellanas receptoras. Los registros de moriscos esclavos o libres, con sus altas y bajas, los repartimientos de los libres entre las distintas poblaciones de acogida o destierro (como queramos denominarlo), las licencias para poder ausentarse de las poblaciones de acogida, los cuadernos de visita si es que existieron, los procesos contra los infractores... forman un conjunto de documentos de notable interés para el conocimiento de esta minoría en las últimas décadas del siglo

${ }^{15}$ En el Archivo Municipal de Toledo se conservan nueve documentos en árabe datados entre 1204 y 1278 que fueron transcritos y reproducidos por A. González Palencia en su obra Los Mozárabes de Toledo en los siglos XII y XIII. Volumen preliminar. Estudio e índices, Madrid, 1930. En concreto están identificados en esa obra con los números 1153-1156, 1158-1159, 1167 y 1173 1174. Su data nos hace pensar que su custodia en este centro obedece a otras motivaciones. 


\section{MARIANO GARCÍA RUIPÉREZ \\ LA EXPULSIÓN DE LOS MORISCOS DEL REINO DE GRANADA EN LOS DOCUMENTOS MUNICIPALES...}

XVI. Aunque, como es obvio y si nos ceñimos a los documentos municipales producidos en esa misma época, la presencia de la población morisca ha podido quedar reflejada en otras series menos específicas como los libros de acuerdos municipales, los padrones tributarios o de otro tipo, las causas civiles y criminales, etcétera $^{16}$. Su huella puede examinarse también en los protocolos notariales de ese periodo histórico y en diferentes procesos inquisitoriales, conservados en diferentes archivos, bien conocidos. Pero sigamos con nuestro análisis basándonos ya en los documentos producidos y no en la legislación.

La formalización de registros de moriscos en las poblaciones receptoras es incluso anterior a la terminación del conflicto armado en el verano de 1570 por lo que la pragmática de 1572 vino a regular y a uniformar una situación que se venía produciendo desde dos años antes. Los envíos a Toledo ${ }^{17}$ de centenares, y a veces miles, de moriscos se constatan claramente ya en el otoño de 1570. Su llegada a la ciudad viene precedida de reales cédulas y de otras disposiciones en las que se da cuenta de su número, de su origen, de la persona a cuyo cuidado están durante el trayecto desde tierras de Granada a Toledo, de la manera en que deben ser repartidos en la ciudad y poblaciones cercanas y de otras contingencias (abastos, etc.). Ya en una Real Cédula de 2 de noviembre de 1570, Felipe II ordenó a las autoridades toledanas, entre otras cosas, que "se haga registro de todas las personas de los dichos moriscos y que se tenga quenta con visitarlos de tiempo en tiempo para que no se ausenten, y que a ninguno se le de licencia para yr a vivir fuera de allí sin espresa liçençia o horden nuestra" 18 .

\footnotetext{
${ }^{16}$ De ellos se da cuenta, por ejemplo, en el breve texto de E. Valero de la Rosa y S. Salvador Vicente titulado "Documentos para el estudio de la expulsión de los moriscos en el Archivo Histórico Provincial de Albacete", aparecido en Anaquel, 45 (abril-junio de 2009), pp. 35-38. Véase también el texto de José María Soler, "Noticias sobre moriscos en el archivo municipal de Villena", Sharq Al-Andalus: Estudios mudejares y moriscos, núm. 1 (1984), pp. 71-90. En el AMT se custodian algunos procesos que afectan a moriscos como el tramitado en 1538 y descrito de la siguiente manera "Causa criminal iniciada en la ciudad de Sevilla a instancia de Pedro de Jerez, vecino de ella, contra Hernando de Frías, morisco, vecino de Toledo, al que acusa de atacar y herir a un esclavo negro de su propiedad y de hurtarle una mula, llevada en apelación ante el alcalde de alzadas de Toledo".

${ }^{17}$ En el estudio de los moriscos toledanos han trabajado especialmente Esperanza Pedraza Ruiz y Francisca Solana Poblete, con estudios pendientes aún de publicación. Entre las aportaciones impresas destacamos las siguientes: M. F. GOMEZ VOZMEDIANO, "Delincuencia y conflictividad morisca en tierras toledanas (ss. XV-XVII)", Anales Toledanos, XXXVII (1999), pp. 67105; B. LOUPIAS, "En marge d'un recensement des morisques de la Villa de El Toboso (1594)", Bulletin Hispanique, vol. 78, 1-2 (1976), pp. 74-96; J. M. MAGAN GARCIA y R. SÁNCHEZ GONZÁLEZ, Moriscos granadinos en la Sagra de Toledo 1570-1610, Toledo, 1993; y H. RODRIGUEZ DE GRACIA, "Un censo de moriscos de finales del Siglo XVI", Toletum, 11 (1981), pp. 521-542.

${ }^{18}$ Esta Real Cédula se conserva en AMT, caja 1686.
} 
LA EXPULSIÓN DE LOS MORISCOS DEL REINO DE GRANADA EN LOS DOCUMENTOS MUNICIPALES...

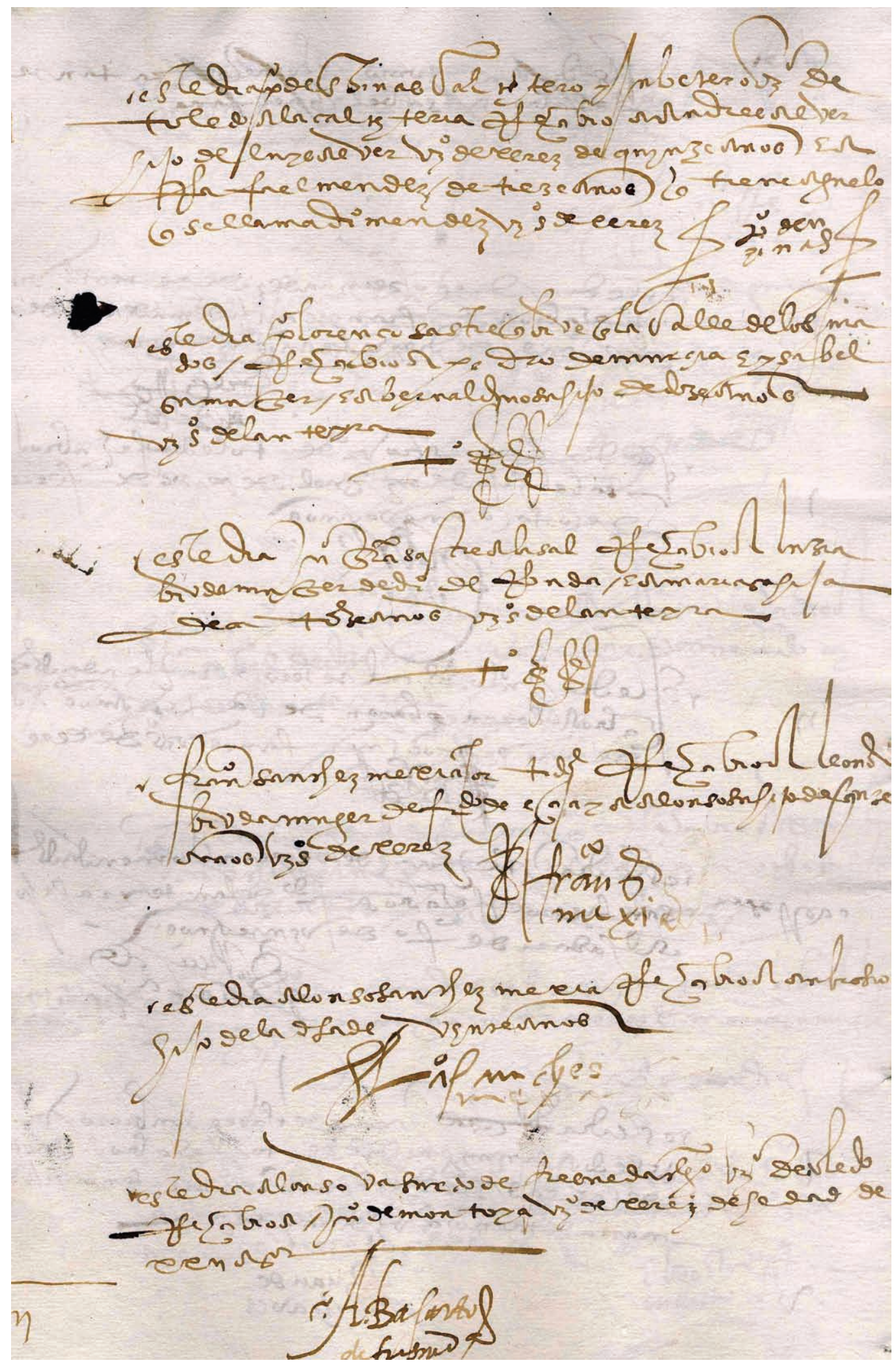

Recibos firmados por los vecinos de Toledo entre los que se repartieron los moriscos (30-XI-1570). 


\section{MARIANO GARCÍA RUIPÉREZ \\ LA EXPULSIÓN DE LOS MORISCOS DEL REINO DE GRANADA EN LOS DOCUMENTOS MUNICIPALES...}

Por ella conocemos, pues, que ya entonces se formalizaban registros de moriscos en las poblaciones de acogida y se tramitaban los expedientes de concesión de licencias para ese tipo de ausencias. Es más, esos registros se hacían primero en los lugares de origen pues la persona que traía al grupo de exiliados, un militar con tropa de pie y a caballo, los recibía allí y los controlaba con la ayuda de un listado que le servía como acta de entrega. En ese listado los moriscos solían estar inscritos, ordenados por su lugar de origen, recogiendo su nombre, edad, estado civil y oficio. Tras llegar a su lugar de destino, después de semanas de viaje caminando, esa lista, con las bajas producidas durante el trayecto, servía para realizar el nuevo registro con los datos de los llegados. A continuación, al menos en esos primeros años, se procedía a su reparto entre los vecinos de Toledo y entre los de sus lugares y aldeas. La distribución entre los primeros quedaba reflejada en relaciones en las que se anotaban los recibos que firmaban los vecinos, indicando en ellos el nombre de los moriscos que pasaban a residir en sus casas. Para los segundos se emitía un mandamiento por el corregidor ordenando a sus alcaldes que acudieran a la ciudad, un día concreto, con carros para transportar hasta sus localidades a los moriscos que les correspondieran. En ellas, tras su llegada definitiva, volverían a ser alistados. Además se emitían distintos autos y requerimientos para garantizar el abasto de pan y otros comestibles (quesos, carne...) necesarios para satisfacer las necesidades de alimento y de transporte de grupos tan numerosos.

Las disposiciones reales, los listados realizados en origen, los registros elaborados en los lugares de acogida, los diferentes repartos, y los autos y otros documentos relacionados con el abasto, con el cuidado de enfermos o con cuestiones derivadas del viaje, formaban lo que podemos denominar como el expediente de repartimiento de moriscos (uno por cada envío), que se conservaba en el ayuntamiento de la ciudad principal, cabeza de corregimiento. Al menos así queda reflejado en Toledo. El proceso se repetía con cada nueva traída de cristianos nuevos desde el Reino de Granada.

La necesidad de controlar el número e identidad de la totalidad de los moriscos que vivían en una determinada localidad o corregimiento, con independencia de la fecha de llegada o de la persona que los había custodiado en el viaje, quedó reflejada incluso antes de la aprobación de la pragmática tanta veces citada de 1572. Así, en Toledo, por una Real Cédula de 22 de marzo de $1571^{19}$, Felipe II quiso que se elaboraran relaciones de los moriscos que habitaban por entonces en la ciudad y su tierra. En los pueblos se contabilizó el número de personas mientras

\footnotetext{
${ }^{19}$ Un ejemplar de esta Real Cédula en ídem.
} 
LA EXPULSIÓN DE LOS MORISCOS DEL REINO DE GRANADA EN LOS DOCUMENTOS MUNICIPALES...

que en la ciudad se recogieron sus nombres. En total, en 3 de abril de 1571, residían en Toledo 1.179 moriscos y en sus aldeas otros 350. Otros muchos habían pasado por Toledo camino de sus lugares de destino definitivo en otras ciudades de Castilla. Y este primer recuento general sería seguido de otro más preciso un año después.

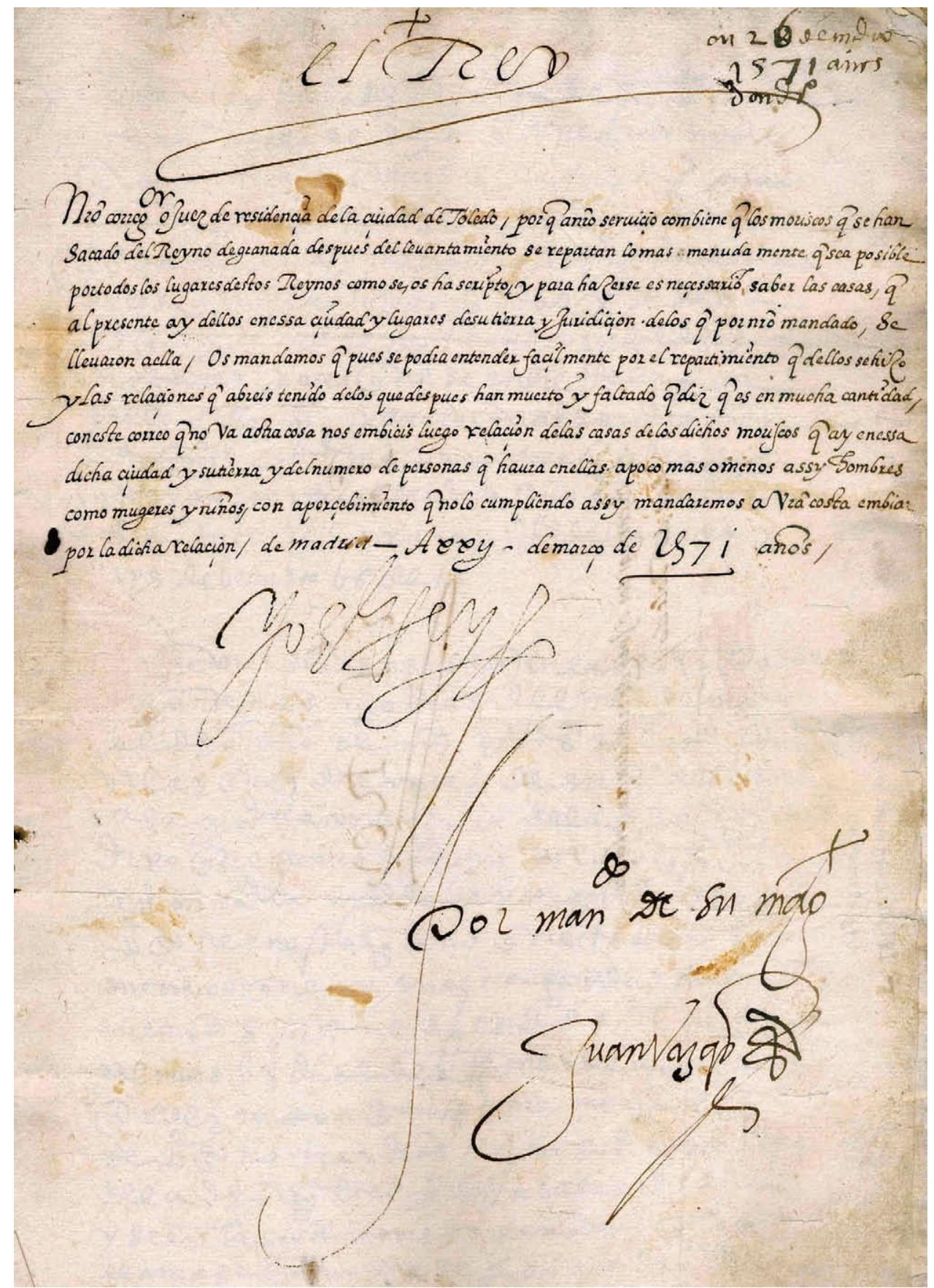

Real Cédula de Felipe II ordenando la realización de nuevos registros (22-III-1571). 


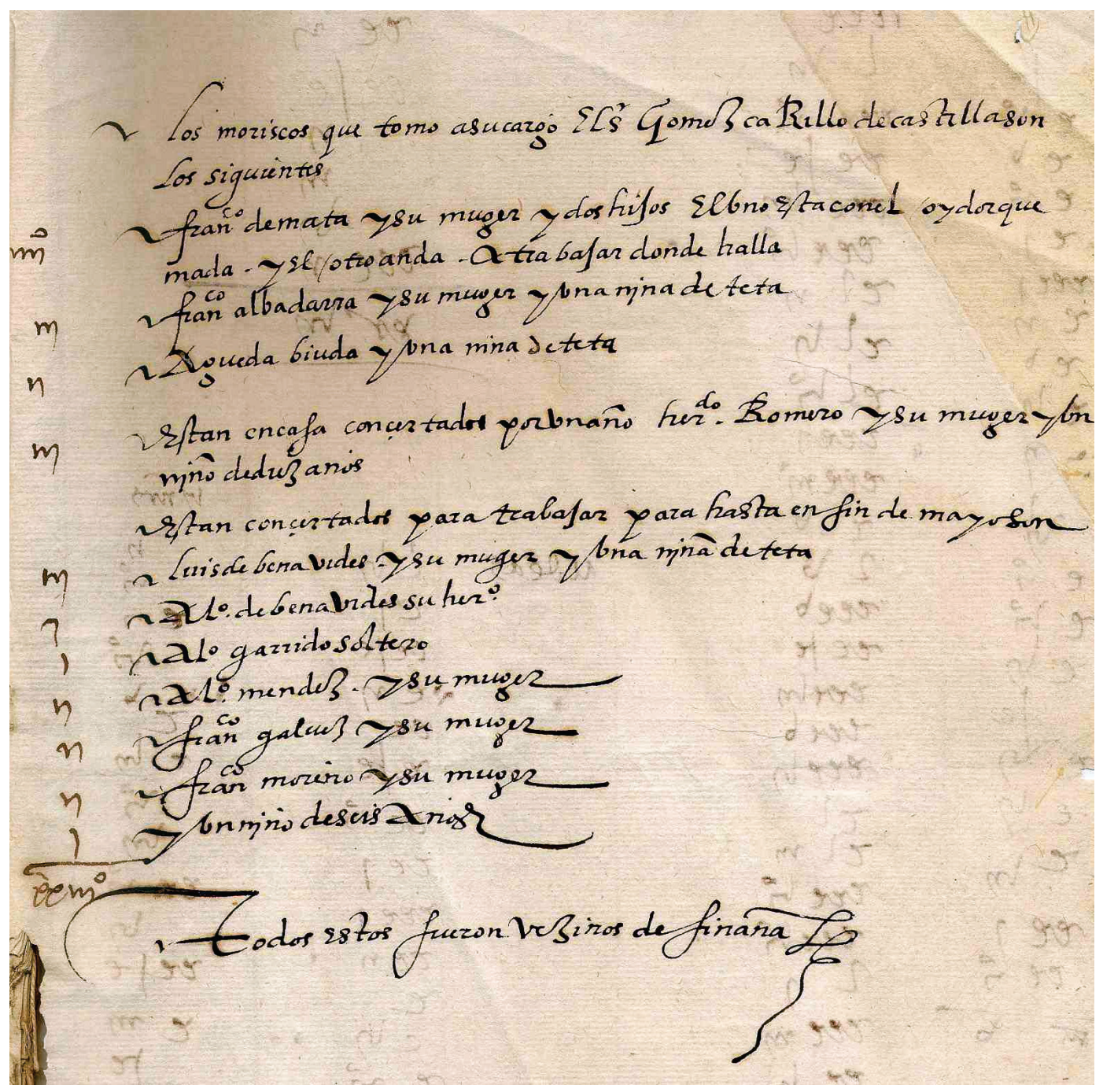

Relación de los moriscos que tiene un vecino de Toledo (III-1572).

Con la aprobación y la publicación de la Pragmática de 26 de octubre de 1572 fue necesario realizar nuevos registros generales, pero ahora en todas las poblaciones de acogida, distinguiendo los moriscos libres de los que tenían la condición de esclavos. En Toledo se elaboraron unas normas para su aplicación. Por ellas sabemos que por pregón sería anunciado el día, víspera de una fiesta, en el que todos los moriscos libres debían juntarse a una determinada hora en un paraje concreto de la ciudad (en el hospital de Santa Cruz o en el de Tavera) ${ }^{20}$. A los esclavos se les asignaría otro lugar. En esas normas se especificaba el contenido

${ }^{20}$ El bando ordenando la reunión de todos los moriscos libres naturales del reino de Granada en el Hospital de San Juan Bautista de Toledo para ser inscritos en el registro el primer día de Pascua fue firmado el 8 de mayo de 1573. Véase AMT, caja 1687. 


\section{MARIANO GARCÍA RUIPÉREZ \\ LA EXPULSIÓN DE LOS MORISCOS DEL REINO DE GRANADA EN LOS DOCUMENTOS MUNICIPALES...}

concreto del registro de la siguiente manera "Anse de poner en el registro los nonbres de cada uno y de dónde son naturales y de qué lugar fueron traídos e la hedad que cada uno tiene y señas destatura e rostro y el ofiçio o ttrato que tubieren e la casa e perroquia donde biven. Y el mismo registro se a de hazer en los lugares de la jurisdicción... y todos los registros se an de poner en un libro. Y en el mismo libro se a de escrevir los que se murieren o faltaren y ansi mesmo los que después binieren o naçieren porque aya quenta con los que oviere" 21 .

En estas instrucciones toledanas se especifica también que "ningún morisco pueda salir del lugar donde se alistare para hazer noche fuera sin particular liçençia firmada de la justiçia y del escrivano del ayuntamiento" y "que se les de liçençia para hir fuera por tienpo limitado teniendo quenta con que si no fuere segura la persona que la pidiere dé seguridad". También tenían que pedir licencia para irse a vivir de un lugar a otro dentro de la ciudad contando con el conocimiento del cura de la nueva parroquia para que los incluyera en su lista.

Por entonces se debieron formalizar escrituras ante los escribanos públicos, tanto en Toledo como en otras poblaciones receptoras, en las que las autoridades locales entregaban a los niños y niñas moriscos a distintos particulares para que les enseñaran un oficio y la doctrina cristiana, y se comprometieran a cuidarlos, a cambio de sus servicios como criados $u$ otros similares ${ }^{22}$. El reparto de estos niños entre los cristianos viejos motivó reclamaciones de sus padres moriscos, pues, como ocurrió en la localidad de Esquivias, las autoridades colocaban a los menores en sus propias casas o en las de sus amistades, tratándoles como si fueran sus esclavos. También hay expedientes motivados por considerar esclavos a niños con una edad inferior a la establecida en la pragmática de 1572. Además, a partir de entonces, debieron formalizarse escrituras de compraventa y manumisión de esclavos moriscos ante los escribanos públicos.

${ }^{21}$ Estas normas se conservan en el AMT, caja 1686.

${ }^{22}$ En el AMT se conserva una copia de una fechada el 26 de enero de 1572 por el que Diego López de Mora recibía a Isabel Mejía, morisca, de manos del corregidor de Toledo, obligándose a darla de comer, beber, vestir, calzar e vida honesta, por un tiempo de cinco años, además la "yndustriará en las cosas de la fee" y no "dirá que es cautiba". Pasados los cinco años Isabel recibiría por sus servicios 5.000 maravedís. Estas escrituras, al formalizarse ante escribano público, se incluyen en los protocolos notariales de esos años, pero en el AMT hay varios contratos de servicio originales copiados en las últimas hojas del Libro registro de esclavos moriscos de 1573 junto con cartas de horro o de libertad por lo que estamos ante documentos que pueden también conservarse en los archivos municipales. 
MARIANO GARCÍA RUIPÉREZ

LA EXPULSIÓN DE LOS MORISCOS DEL REINO DE GRANADA EN LOS DOCUMENTOS MUNICIPALES...

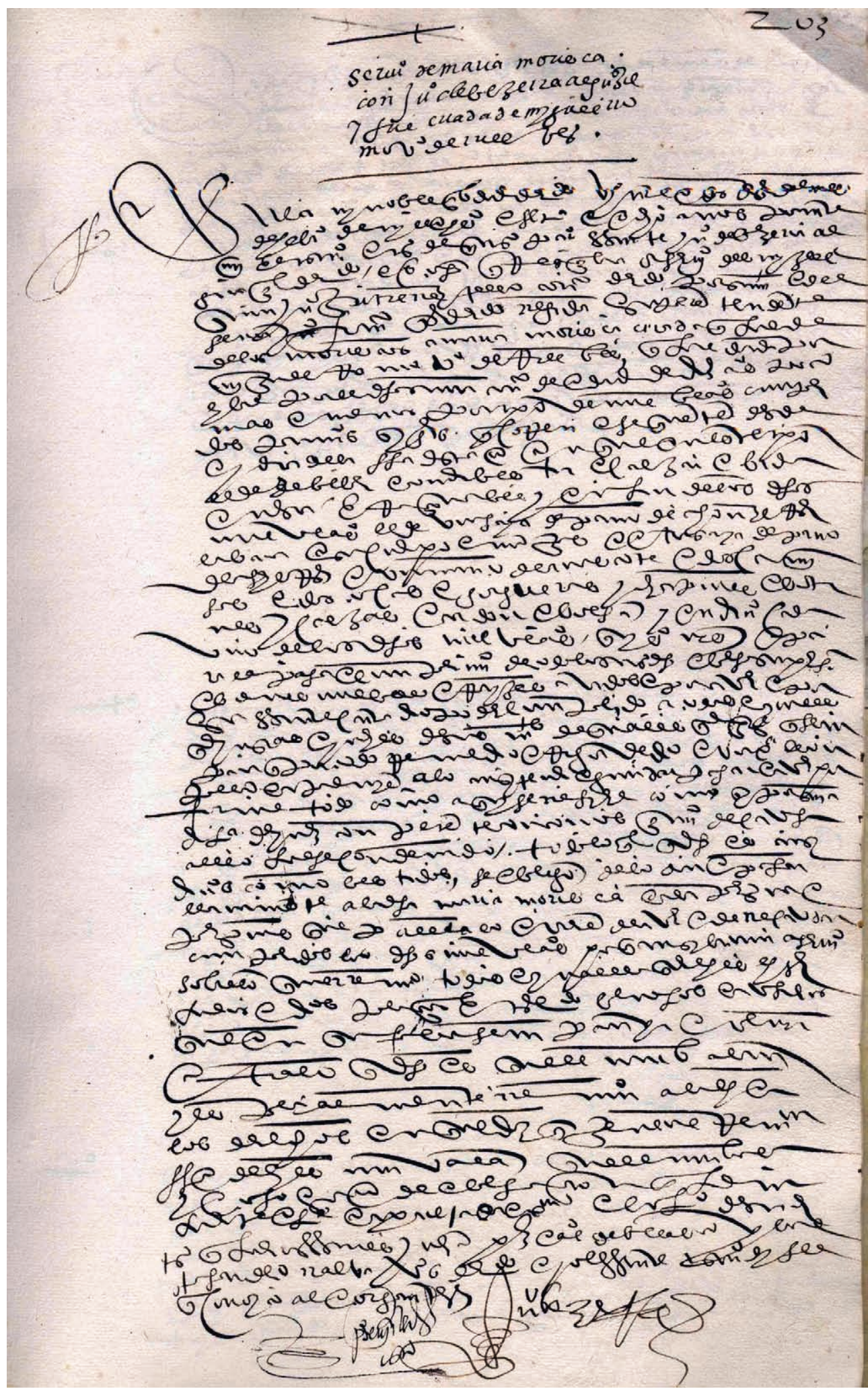

Contrato de servicio como criada de una morisca (22-II-1578). 
Los registros generales de moriscos efectuados con posterioridad a la aprobación de la Real Pragmática de 26 de octubre de 1572 son mucho más completos que los anteriores al incluir los nombres de todos los miembros de la unidad familiar, su edad, sus principales rasgos físicos, su lugar de origen, su oficio, la casa en la que vivían, etcétera ${ }^{23}$, y, lo más importante, recoger esos datos de todos los cristianos nuevos que vivían en esa población, sin tener en cuenta su fecha de llegada. Por ello en las fuentes se les denomina como "alistamiento general de moriscos".

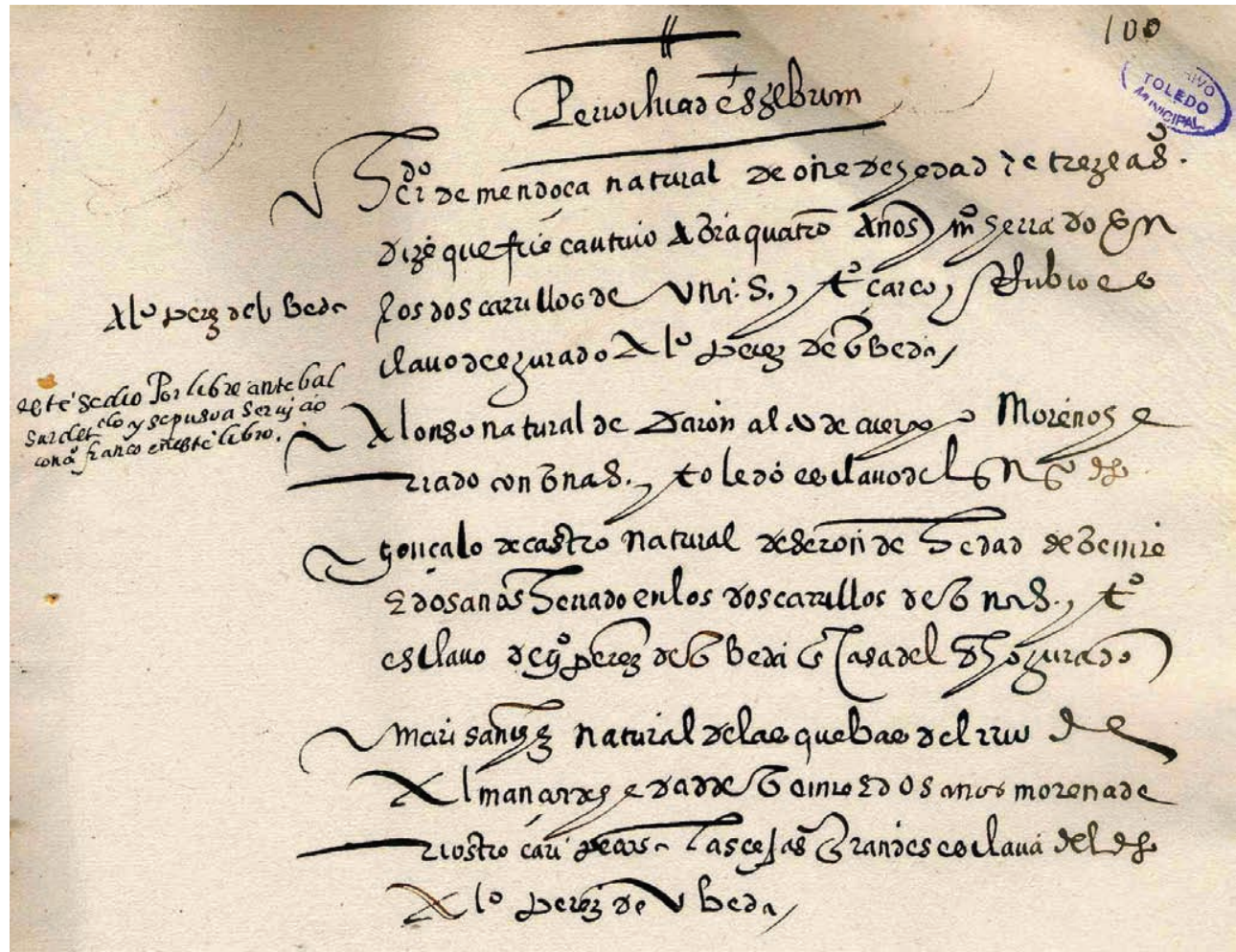

Registro de moriscos esclavos de la ciudad de Toledo (1573).

Tal y como indicaba la Pragmática de 26 de octubre de 1572 se confeccionaron dos listas diferentes, una que contenía los datos de los moriscos libres y otra

${ }^{23}$ Como ejemplo puede servirnos el registro de una morisca en la localidad de Navalmoral de Toledo realizado el 22 de junio de 1573. En concreto se dice de ella lo siguiente: "Registrose María d[e] Escalante, morisca, natural de la villa de Benauxar, tierra de Rronda, y dixo ser de hedad de quarenta años, ques una muger de buen cuerpo, flaca de rrostro, mellada los dientes de la parte de arriba de dos de ellos, arrugada el rrostro y dixo ser labrandera y bive en las casas de la Menora hija de Alonso Camino, vecino de este dicho lugar, y es biuda y tiene tres hijos, y la una casada que se llama Mari Páez y su marido Hernán Garçía y el ottro Juan y la ottra Juana, la mucha[cha] de siete y el mu[cha]cho de diez y la casada de veinte años". Véase este registro en AMT, caja 1687. 
con los de los moriscos esclavos. En Toledo, estos últimos fueron registrados por parroquias y dentro de éstas por los nombres de sus propietarios que quedaban recogidos en su descripción. También en ella aparecía si el esclavo estaba o no marcado (herrar es el término utilizado en la época), generalmente en el rostro ${ }^{24}$.

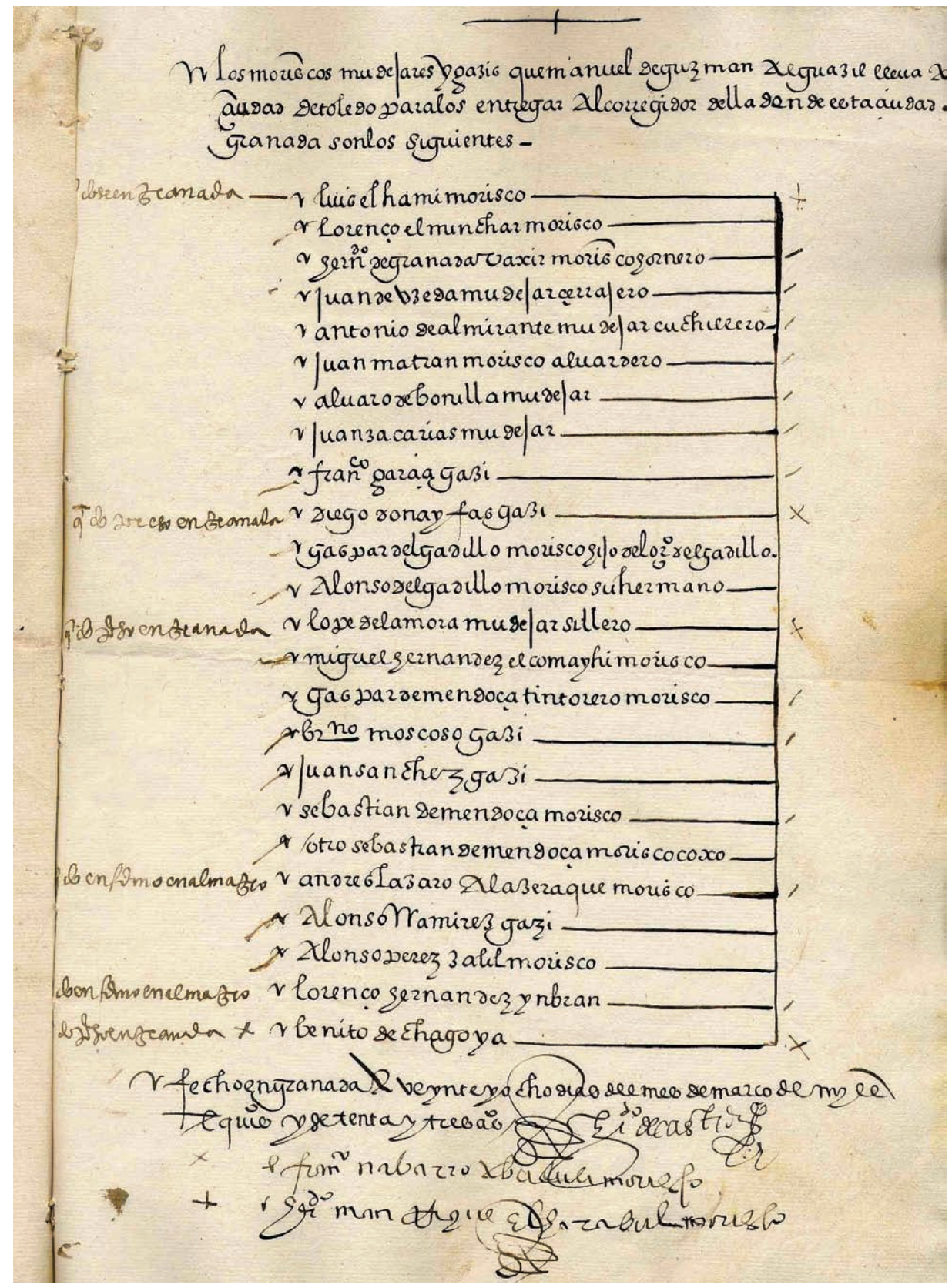

Lista de moriscos enviados a Toledo realizada en Granada (8-III-1573).

${ }^{24}$ El libro registro de moriscos esclavos del año 1573 de la ciudad de Toledo se conserva en el AMT, Libros Manuscritos, sección B, núm. 174. 
A partir de 1573 los envíos de moriscos desde el Reino de Granada se van espaciando en el tiempo aunque a Toledo llegaron grupos, eso sí, menos numerosos, todavía en los primeros meses de 1576, precedidos de una disposición de $\mathrm{Fe}$ lipe II dando cuenta a las autoridades locales de la llegada de los nuevos exiliados. Incluso un pequeño grupo de los rebelados en las serranías de Ronda y Marbella fue entregado en Toledo en mayo de 1577.

Un nuevo registro general de moriscos libres, alistados por parroquias, fue realizado en Toledo en el año 1580 y en él se anotaron las altas y bajas producidas en esa relación hasta mediados del año 1582. Desconocemos el motivo de su realización, si obedeció o no a una nueva disposición regia o fue una decisión autónoma de las autoridades locales. De todas formas es posible que se hicieran más registros con posterioridad, si no totales al menos parciales.

Junto con los iniciales expedientes de repartimiento de moriscos en las poblaciones de acogida, los registros generales realizados en fechas concretas y las modificaciones anotadas en ellos con posterioridad (muertes, cambios de domicilio... ${ }^{25}$ ) para el control de esta minoría se tramitaron, además, otro tipo de expedientes. Los más numerosos fueron los de inclusión o alta en el alistamiento general (también los hay de baja) y los de concesión de licencia para poder ausentarse por tiempo limitado.

En esos años fue bastante habitual que los moriscos solicitaran a las autoridades locales su inclusión o su baja en el alistamiento general en el que estaban registrados. Su deseo de movilidad, su cambio de lugar de residencia, se basaba generalmente en la búsqueda de la reunificación familiar o en motivos económicos. Pero ese cambio de localidad de acogida implicaba que fuera autorizado previamente por disposición regia, tal y como estaba establecido en la Pragmática de 26 de octubre de 1572. Para conseguir que fuera incluido en el alistamiento general de moriscos realizado en la población en la que quería residir era preciso que el cristiano nuevo presentara ese documento, generalmente una real provisión, ante su autoridad municipal (alcalde, corregidor o sus tenientes). Esta se limitaba tras su lectura a obedecerla y a ordenar su cumplimiento. Inmediatamente el escribano procedía a su inclusión en el registro recogiendo su nombre, el lugar de naturaleza, su oficio, su edad, sus rasgos físicos más significativos y la parroquia o casa donde fijaba su residencia. Todo quedaba reflejado, la mayoría de las veces, en un testimonio de verdad dado por el escribano en el que daba cuenta de

\footnotetext{
${ }^{25}$ En el Archivo Municipal de Toledo se conserva un expediente de 1595 por el que se solicita mejorar la descripción de un morisco que en el registro de 1573 figuraba tan solo que era un niño de cuatro años sin ni siquiera recoger su nombre.
} 
todo lo actuado, que se iniciaba, por lo tanto, con la copia de esa disposición regia, pues el documento original quedaba en poder del propio morisco. Este procedimiento podía complicarse si en la inclusión en la lista de moriscos intervenía alguna otra autoridad, era el resultado de un proceso judicial o se producía cualquier otra incidencia.

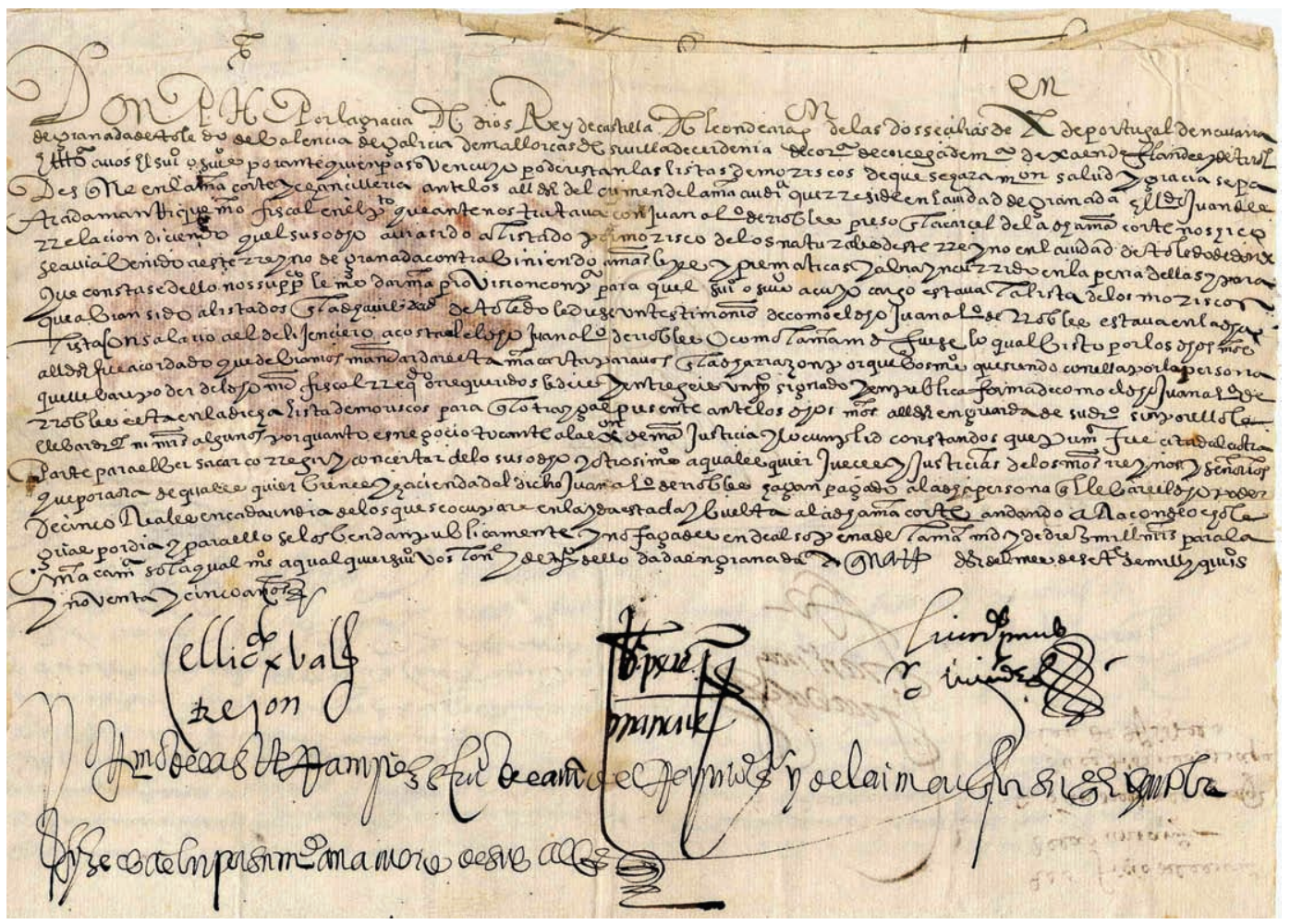

Real Provisión sobre la inclusión de un morisco en el registro de moriscos de Toledo (4-IX-1595).

Pero no todos los expedientes de altas en el alistamiento general de los moriscos se iniciaban con la presentación de una disposición regia por el peticionario. Los había más sencillos. Entre éstos estaban los tramitados por los cristianos nuevos para incluir en ese registro a sus hijos nacidos después de 1573. Para fundamentar su solicitud la acompañaban de un testimonio o de un certificado del cura de la parroquia dando cuenta de que habían sido bautizados.

Más numerosos entre los expedientes de altas son los tramitados tras la consecución de una carta de horro o de libertad por moriscos que hasta entonces habían sido esclavos. Una vez conseguida la libertad, el cristiano nuevo se presentaba ante la autoridad local de la población en la que quería fijar su residencia exhibiendo esa carta o escritura para solicitar ser alistado como morisco libre en el registro mandado hacer por Felipe II. La autoridad, generalmente el alcalde o el corregidor, tras examinar la carta de horro, mandaba que se trasladara su conteni- 


\section{MARIANO GARCÍA RUIPÉREZ \\ LA EXPULSIÓN DE LOS MORISCOS DEL REINO DE GRANADA EN LOS DOCUMENTOS MUNICIPALES...}

do al promotor fiscal para que hiciera las observaciones oportunas. Notificado el auto al fiscal, éste informaba de la conveniencia de la inclusión del antiguo morisco esclavo en el registro general. Después, el mismo día de la solicitud o al día siguiente, la autoridad local mandaba por auto su alistamiento ${ }^{26}$. También hay expedientes de altas en el alistamiento en la que los moriscos implicados argumentan que desconocen la localidad en la que fueron registrados tras su expulsión del Reino de Granada dada la corta edad que tenían entonces, o por otras razones ${ }^{27}$.

Pero la mayor parte de los documentos generados en relación con esta minoría en los ayuntamientos de las poblaciones de acogida, posteriores a 1572, se refieren a la concesión de licencias a los moriscos para que se ausentaran de esas localidades por un tiempo limitado. En esos expedientes, el auto definitivo dictado por una autoridad local va precedido de la petición y de una información testifical, con testimonios de varias personas, en la que se acredita ser ciertos los argumentos expuestos por el morisco en su pedimento, ya que si se marchaba sin estar autorizado y era detenido se seguía contra él el correspondiente proceso judicial con las penas ya conocidas contempladas en la Pragmática de 26 de octubre de 1572. Lo habitual, también, es que se les exigiera la presentación de fiadores que se comprometían por escrito, con sus bienes y sus personas, a favor del cristiano nuevo solicitante. Es decir, el expediente tipo estaba formado por la petición, el auto de la autoridad ordenando que presentara testigos, las declaraciones de éstos (información testifical), el auto concediendo la licencia o pasaporte bajo determinadas condiciones (periodo de vigencia, ámbito geográfico, presentación de fianzas, penas por incumplimiento, etc.) y el testimonio o la escritura de fianza. Son expedientes muy sencillos, de unas pocas hojas, pero muy corrientes. Baste ahora indicar que entre marzo y agosto de 1596 (cinco meses) se registraron 84 escrituras de fianzas en Toledo autorizando a otros tantos moriscos a desplazarse a Murcia, Sevilla, Pastrana, Valladolid, Jaén, Córdoba, etc. Por ello no nos debe extrañar que estas escrituras se realizaran utilizando un formulario impreso en el que se debía rellenar con letra manuscrita únicamente la data, el nombre del fiador, el del morisco solicitante, el periodo de licencia, el lugar o zona a donde podía ir, los nombres de los testigos y la firma y rúbrica del escribano ante el que se formali-

\footnotetext{
${ }^{26}$ Un expediente de este tipo se conserva en el AMT a petición del morisco Diego de Morales, esclavo que fue de los marqueses de Villena. Las actuaciones comentadas se realizaron entre los días 19 y 20 de abril de 1583.

${ }^{27}$ El morisco Garci Vázquez argumentó en 26 de enero de 1588 ante las autoridades toledanas que al estar casado con una cristiana vieja no estaba obligado a ser alistado.
} 
LA EXPULSIÓN DE LOS MORISCOS DEL REINO DE GRANADA EN LOS DOCUMENTOS MUNICIPALES...

$\mathrm{zaba}^{28}$ y se conservaran todas juntas originales, una detrás de otra ordenadas cronológicamente, agrupadas formando un registro de escrituras de fianzas, incluyendo en el expediente una anotación del escribano dando cuenta de que se había formalizado esa escritura, pero sin incluir en él el texto original.

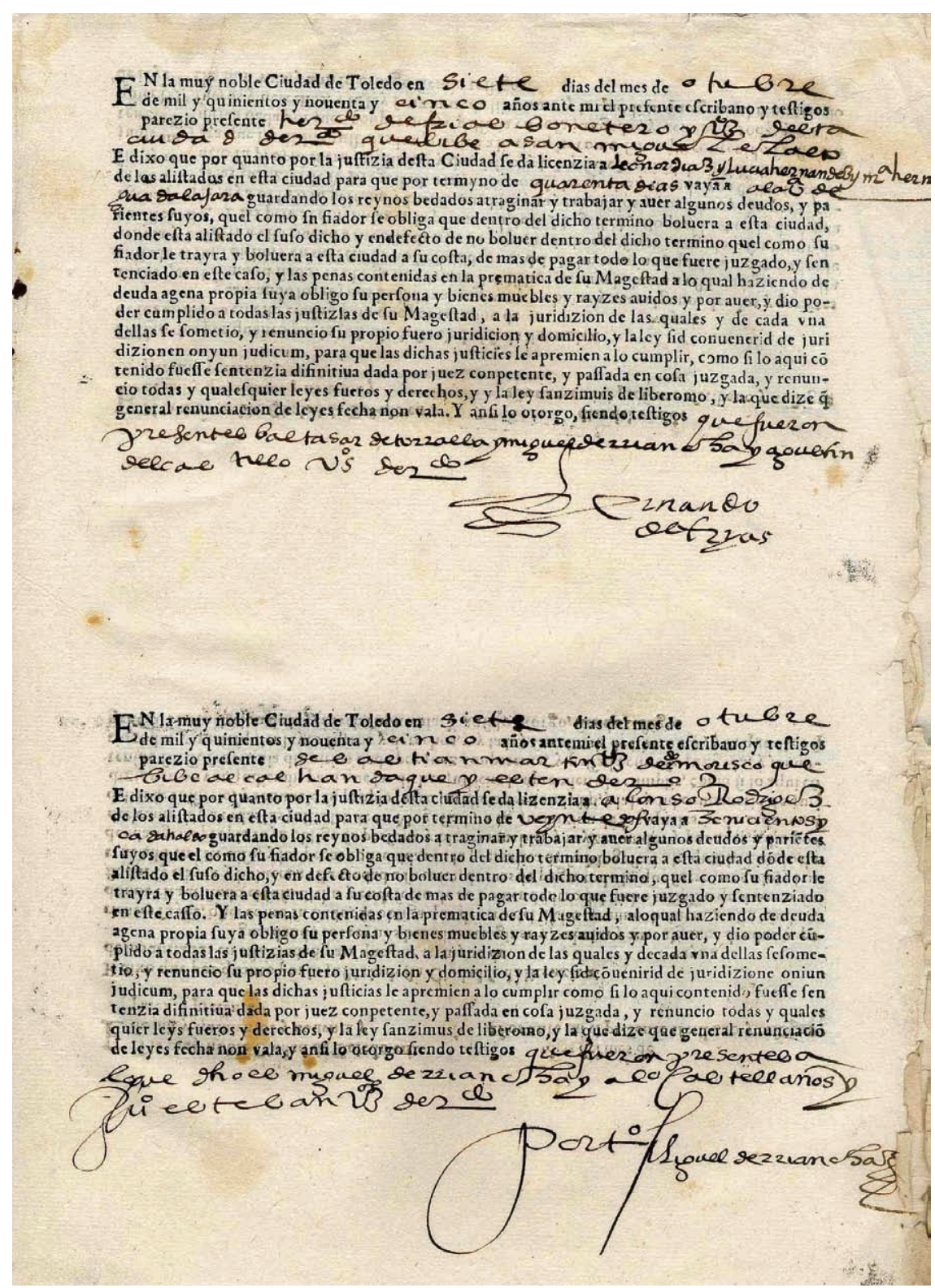

Registro de escrituras de fianza dadas a favor de los moriscos de Toledo (1595).

${ }^{28}$ Entre los años 1595 y 1599 se datan ejemplos de estas escrituras de fianzas presentadas por los moriscos y redactadas sobre formularios impresos entre los documentos del AMT. Y también las hay totalmente manuscritas. Así, en concreto en este Archivo se conserva un registro en el que están asentadas más de sesenta escrituras de fianza con esta finalidad y datadas entre el 13 de mayo de 1573 y el 7 de septiembre de 1574 . 


\section{MARIANO GARCÍA RUIPÉREZ \\ LA EXPULSIÓN DE LOS MORISCOS DEL REINO DE GRANADA EN LOS DOCUMENTOS MUNICIPALES...}

Esas licencias o pasaportes, como también se les denomina, eran expedidas, o debían serlo, de forma gratuita, sin que se les exigieran derechos, por los escribanos de concejo o ayuntamiento con arreglo a las disposiciones regias. Las licencias de ausencia de la localidad de acogida por tiempo limitado, firmadas por la autoridad local (alcalde o corregidor) y por el escribano del concejo o ayuntamiento, por su condición de documentos municipales expedidos, no suelen conservarse en los ayuntamientos españoles al no ser habitual en aquel periodo la realización de $\operatorname{copias}^{29}$.

La mayoría de estas licencias eran solicitadas por moriscos dedicados a la arriería o a alguna otra actividad que requería su ausencia temporal de la localidad de acogida para poder subsistir. No faltan tampoco peticiones de licencias relacionadas con la reunificación familiar, con el cobro de deudas, con herencias, etc., pero son menos habituales. Y si el traslado era definitivo se requería, como sabemos, autorización del rey, siguiendo un procedimiento muy similar al de los expedientes de altas en el alistamiento ya comentados. En estos casos en la localidad de origen se recibía un testimonio firmado por un escribano público en el que daba cuenta de la inscripción del cristiano nuevo en el registro en la población de destino.

Ante esos escribanos continuaron tramitándose también cartas de horro o de libertad de esclavos moriscos en esos últimos años del siglo XVI en las que pudieron participar las autoridades locales, aunque ahora se conserven mayoritariamente en los respectivos protocolos notariales ${ }^{30}$.

Resumamos, las series documentales más significativas surgidas tras la expulsión de los cristianos nuevos del Reino de Granada en 1570 que se conservan, o deberían conservarse, en los archivos municipales de las poblaciones de destino, son, entre los expedientes, los de repartimiento de moriscos en las poblaciones de acogida, los de altas y bajas en el alistamiento general de moriscos libres, y los de concesión de licencias para ausencias temporales. A estas series formadas por expedientes debemos unir dos tipos de registros, los registros generales de moriscos con sus modificaciones (altas, bajas...) en los que estaban inscritos, en listas o

${ }^{29}$ No obstante en el AMT hay varias de estas licencias, o pasaportes, expedidas tanto por autoridades toledanas como de otras poblaciones lo que nos permite conocer sus características tipológicas y su contenido informativo ya de una forma más concreta.

${ }^{30}$ En el Archivo Municipal de Toledo existe copia de una de estas cartas, fechada el 25 de septiembre de 1582. La liberación del esclavo Diego de Orce se debió a que cuando fue apresado y marcado tenía tan solo siete años. Su madre Isabel acudió a las autoridades de La Membrilla (Ciudad Real), en donde estaba cautivo, para conseguir su liberación. Véase la carta de horro en AMT, caja 1687. 


\section{MARIANO GARCÍA RUIPÉREZ \\ LA EXPULSIÓN DE LOS MORISCOS DEL REINO DE GRANADA EN LOS DOCUMENTOS MUNICIPALES...}

libros diferentes, por un lado los que tenían la consideración de libres y por otro los que eran esclavos, y los registros de escrituras de fianzas. Todas ellas tienen un fundamento normativo claro basado en el contenido de la Real Pragmática de 26 de octubre de 1572.

Si analizamos la Nueva Recopilación... o la Novísima Recopilación... sorprende que en esas publicaciones oficiales apenas se recojan normas relacionadas con la minoría morisca posteriores a 1572. Una de ellas se data el 3 de septiembre de 1585. Felipe II ordenó en esa fecha que los pedimentos y demandas realizados por algunos moriscos expulsos relacionados con su interés por ser declarados cristianos viejos solo podían tratarse ante el Consejo de Población creado en Granada, y no ante cualquier otro tribunal. Entendía el Rey que era ese Consejo, formado por miembros de la Chancillería de esa ciudad, el que tenía información precisa para conocer si sus peticiones eran legítimas, porque sus antepasados se hubieran convertido antes de 1502 o por otras causas ${ }^{31}$. Los procesos iniciados por este motivo ante diferentes justicias debían enviarse a ese Tribunal para su resolución $^{32}$. También en la Novísima... se recogió que en las Cortes celebradas en Madrid, en 1593, y en relación con la petición número 30, el Rey ordenó de nuevo a las justicias de sus Reinos que cumplieran las leyes aprobadas sobre el "orden y forma que se ha de tener y guardar con los Moriscos"33. Como sabemos, multitud de disposiciones regias, la mayoría reales provisiones, fueron emitidas por el Consejo Real para facilitar la inclusión de determinados moriscos en los alistamientos generales pero siempre a título particular.

La normativa aprobada en 1572 fue el marco jurídico que reguló la existencia de los moriscos del Reino de Granada en las décadas siguientes, hasta la aprobación de su definitiva expulsión ocurrida casi cuarenta años después.

Los problemas de la Real Hacienda a principios del siglo XVII motivaron la formalización de un asiento general entre los representantes de la minoría moris-

31 Ídem, Libro Octavo, Título II, Leyes XX, h. 298v-299. Esta Real Provisión fue dada en Monzón el 3 de septiembre de 1585, y no el 23 de septiembre de 1582 como se indica en la Novísima Recopilación... Su texto fue publicado en un folleto titulado Provisión Real de su Magestad, sobre la orden se ha de tener en los negocios tocantes a los Moriscos del Reyno de Granada, que pretendien ser Christianos viejos, en Madrid: en casa de Guillermo Droy, Impressor de Libros, año 1585. Su contenido ha sido analizado por M. J. García Gómez en el texto titulado "La Provisión Real del 3 de septiembre de 1585: los procesos sobre la condición social de los moriscos" aparecido en La administración de Justicia en la Historia de España: Actas de las III Jornadas de Castilla-La Mancha sobre investigación en Archivos, Tomo I, Toledo, 1999, p. 169-192.

${ }^{32}$ Esos procesos y el archivo del Consejo de Población se custodian en el Archivo de la Real Chancillería de Granada.

33 Ídem, Libro Octavo, Título II, Leyes XXI, h. 299. 


\section{MARIANO GARCÍA RUIPÉREZ \\ LA EXPULSIÓN DE LOS MORISCOS DEL REINO DE GRANADA EN LOS DOCUMENTOS MUNICIPALES...}

ca, a través de procuradores comisarios de "los naturales del Reyno de Granada, Mudéjares y Gazis de la Corona de Castilla y León”, y el rey Felipe III. Las 18 capitulaciones recogidas en este asiento están firmadas en Valladolid el 7 de noviembre de $1602^{34}$. Por ellas los moriscos se comprometían a entregar 240.000 ducados en las arcas reales, pagados en ocho años, a razón de 30.000 ducados anuales a contar desde 1603. En la capitulación número $1^{a}$ figura su petición de que se les tuviera por cristianos viejos a lo que Felipe III contestó "mandaré se mire en ello, con desseo de les hazer merced". Con independencia del contenido de los siguientes acuerdos relacionados con el repartimiento y pago de la cantidad acordada que sería empleada en "ayuda a las necesidades causadas de la defensa de la Fe", nos interesa este texto porque estableció que las "listas que para el repartimiento deste servicio se han de hazer de los dichos naturales, sirvan de listas y vezindades en las partes y lugares donde se hallaren" (capitulación $2^{\mathrm{a}}$ ). Es decir, que de su aplicación se seguiría la realización cada año de un listado de moriscos en las localidades en las que residieran incluyendo la cantidad que les correspondía pagar del servicio acordado, a manera de lista cobratoria.

En la capitulación $3^{\mathrm{a}}$ de este asiento general de $1602^{35}$, el Rey les autoriza a que puedan cambiar de residencia por obligaciones y causas justas, previa información testifical, siempre que contaran con licencia de las justicias de los lugares en los que vivieran y se diera noticia de ello al "Consejo de Justicia", en referencia posiblemente a la Sala de Justicia del Consejo de Castilla. O sea, ya no presupone la previa autorización real como recogía la Pragmática de 1572. Además, en la capitulación $5^{\mathrm{a}}$, establece que las licencias para ausencias dadas a trajineros y arrieros moriscos tuvieran una validez de cuatro meses, y que no se precisasen estas autorizaciones para los moriscos que tenían que salir de las localidades a labrar sus heredades y huertas y precisaban dormir en ellas.

Este asiento general solo afectaba a los moriscos que vivían dispersos en poblaciones de los reinos de Castilla y León y que en su gran mayoría procedían o eran descendientes de los que fueron expulsados del Reino de Granada tras la sublevación de las Alpujarras. Todos ellos no llegaban a representar ni el 2\% de la

${ }^{34}$ El contenido de este asiento general lo conocemos por un traslado impreso conservado en el AMT (signatura 6420) dentro de una causa criminal tramitada entre noviembre y diciembre de 1608 y descrita de la siguiente manera: "Causa por alistamiento indebido iniciada de oficio contra Hernando Gutiérrez, morisco, al que acusan de haberse ido a vivir a la parte de Yébenes de San Juan, procedente de Yébenes de Toledo, sin tener pasaporte".

${ }^{35}$ No sabemos si se formalizó otro asiento general con anterioridad pero en el comentado se indica que los comisarios que intervenían en él recibirían "las comissiones que se les dieron el año passado de noventa y siete". 
MARIANO GARCÍA RUIPÉREZ
LA EXPULSIÓN DE LOS MORISCOS DEL REINO DE GRANADA EN LOS DOCUMENTOS MUNICIPALES...

población castellana. En los reinos de Aragón y Valencia este porcentaje era mucho mayor, pues la población morisca alcanzaba el $20 \%$ en el primer reino y más del $30 \%$ en el segundo.

No nos vamos a detener en las causas de la expulsión de los moriscos de España, tanto de poblaciones de la corona de Castilla como de la de Aragón, pues no es el objeto de nuestro estudio, pero sí vamos a referirnos brevemente a su reflejo documental, siempre centrándonos en poblaciones castellanas con presencia de moriscos del antiguo Reino de Granada, como hemos hecho hasta ahora.

La Pragmática de 9 de diciembre de 1609 generalizó las medidas aprobadas meses antes y que afectaban a los moriscos del Reino de Valencia. La decisión de Felipe III de expulsar a todos los "moriscos habitantes en estos reinos y prohibición de volver a ellos" implica el reconocimiento del fracaso de todas las medidas anteriores, pues en la introducción de esa disposición afirmaba que "ninguno se ha convertido". Por una Real Cédula, dada en Madrid el 28 de diciembre de 1609, se extendía su contenido a los moriscos que habitaban en los reinos de Castilla la Vieja, la Nueva, Extremadura y La Mancha ${ }^{36}$. Sus bienes inmuebles fueron confiscados y solo se les permitió vender sus bienes muebles y semovientes para, con lo obtenido, poder comprar mercancías no vedadas y con ellas, y con el dinero que pudieran necesitar para el viaje, abandonar España ${ }^{37}$. El Rey les daba el plazo de un mes para su salida desde la fecha de la publicación de esa norma, con la condición de que en su marcha no pasaran por Andalucía, ni por los reinos de Granada, Murcia, Valencia o Aragón, bajo pena de muerte. Una Real Cédula de 13 de enero de 1610, con un contenido similar, ordenó la expulsión de los moriscos de los reinos de Granada, Murcia y Andalucía.

El proceso de expulsión iniciado en 1609 se demoró por distintas causas dependiendo de las localidades y de los reinos ${ }^{38}$. Los documentos generados por esos años en los ayuntamientos de las poblaciones de acogida o de destierro de los moriscos granadinos están relacionados especialmente con la administración y venta de los bienes inmuebles pertenecientes a esta minoría y que quedaron en

${ }^{36}$ Esta Real Cédula fue publicada, en Madrid, el 2 de enero de 1610. Otras disposiciones extenderán su aplicación a otras partes de España.

${ }^{37}$ F. J. MORENO DÍAZ DEL CAMPO, “Geografía de la expulsión morisca: aproximación al análisis de la administración y venta del patrimonio de los moriscos expulsados de la Corona de Castilla", Chronica nova: Revista de historia moderna de la Universidad de Granada, 31 (2005), pp. 379-426.

${ }^{38}$ Por una Real Cédula dada en Madrid, el 21 de agosto de 1612, Felipe III mandaba a las justicias de sus reinos que cumplieran las órdenes dadas sobre la expulsión de los moriscos, y por otra firmada en El Escorial, el 19 de septiembre de ese mismo año, determinaba la manera de trasladar a los puertos a los que por su pobreza no tenían medios para poderlo realizar. 
poder de la Corona. Hay por lo tanto expedientes de nombramientos de receptores de esos bienes, de ampliación de plazos para el cumplimiento de las disposiciones comentadas, de reclamaciones de moriscos para no ser expulsados indicando que eran cristianos viejos, etc. No faltan procesos contra moriscos que pretendieron eludir la expulsión escondiéndose, incluso en lugares muy apartados. Y algunos lo consiguieron. Pero las consecuencias de las medidas adoptadas fueron traumáticas para otros muchos españoles que seguían profesando la religión musulmana y que tuvieron que abandonar definitivamente su casa, su ciudad y su patria.

Todavía décadas después, Felipe IV ordenó al corregidor de Toledo, por una Real Provisión de 12 de octubre de $1643^{39}$, que averiguase los bienes que quedaban sin vender de los moriscos expulsos en los lugares de su jurisdicción y procediera a su enajenación.

${ }^{39}$ Un ejemplar de esta Real Provisión se conserva en el AMT, caja 1689. 